OPEN ACCESS

Edited by:

$S P L i$,

University of Macau, SAR China

Reviewed by:

Yongsheng Chen, Jinan University, China

Ke Song,

Jilin University, China

*Correspondence:

Wei-ming Wang

113561153193@126.com

Specialty section: This article was submitted to

Ethnopharmacology,

a section of the journal

Frontiers in Pharmacology

Received: 20 August 2021 Accepted: 27 September 2021 Published: 04 November 2021

Citation: Liu Z, Huo J-h, Dong W-t, Sun G-d, Li F-j, Zhang Y-n, Qin Z-w, pengna J and Wang W-m (2021) A Study Based

on Metabolomics, Network

Pharmacology, and Experimental Verification to Explore the Mechanism of Qinbaiqingfei Concentrated Pills in

the treatment of

Mycoplasma Pneumonia.

Front. Pharmacol. 12:761883.

doi: 10.3389/fphar.2021.761883

\section{A Study Based on Metabolomics, Network Pharmacology, and Experimental Verification to Explore the Mechanism of Qinbaiqingfei Concentrated Pills in the treatment of Mycoplasma Pneumonia}

\author{
Zheng Liu ${ }^{1}$, Jin-hai Huo ${ }^{1}$, Wen-ting Dong ${ }^{1}$, Guo-dong Sun ${ }^{1}$, Feng-jin $\mathrm{Li}^{1}$, Ya-nan Zhang ${ }^{1}$, \\ Zhi-wei Qin ${ }^{1}$, Jiang pengna ${ }^{2}$ and Wei-ming Wang ${ }^{1 *}$ \\ ${ }^{1}$ Heilongjiang Academy of Chinese Medicine, Institute of Chinese Materia Medica, Harbin, China, ${ }^{2}$ Heilongjiang University of \\ Chinese Medicine, Harbin, China
}

Qinbaiqingfei concentrated pills (QB) are a commonly used medicine for the treatment of mycoplasma pneumonia in China, and the mechanism of action of QB needs to be studied further. Therefore, we use a combination of metabolomics and network pharmacology to clarify the mechanism of QB. Nontarget metabolomics studies were performed on rat serum, urine, and lung tissues, and 56 therapeutic biomarkers were found. Subsequently, the components of QB absorbed into the blood and lung tissues were clarified, and based on this finding, the core target of network pharmacology was predicted. The enrichment analysis of biomarkers-genes finally confirmed their close relationship with the NF-kB signaling pathway. By western blotting expression of the proteins in the lung tissue-related signaling pathways, it is finally confirmed that $Q B$ inhibits the $N F-\kappa B$ signaling pathway through SIRT1, IL-10 and MMP9, CTNNB1, EGFR, and other targets. It plays a role in regulating immunity, regulating metabolism, and treating diseases.

Keywords: Qinbaiqingfei concentrated pills, metabolomics, network pharmacology, NF-kB signaling pathway, mycoplasma pneumonia

\section{INTRODUCTION}

Mycoplasma pneumoniae (MP) infection is a common source of community-acquired infection. Mycoplasma pneumoniae pneumonia (MPP) is a common infectious disease in children (Alishlash et al., 2019). Current evidence shows that the incidence of MPP in children over 4 years of age is significantly higher than that in other age groups (Waites et al., 2017). Researchers have found that MPP infection is closely related to climatic changes (Onozuka et al., 2009; Xing et al., 2020). Its outbreak can cause serious community infections (Bajantri et al., 2018). Although MPP is a selflimited disease with pulmonary symptoms occurring in only about 3-13\% of patients (Saraya, 2017), about 3.5 million people have died of mycoplasma pneumonia (World Health Organization) every year since it was first reported clinically by Dr. Reimann in 1938.

MP, as the smallest pathogen currently discovered, can activate the immune process by inducing tissue damage through adhesion to host epithelial cells (Atkinson et al., 2008). Adhesion to cells surfaced by adhesin P30 and P1 protein prevents removal (Waites et al., 2008). Next, the release of 
superoxide anions and toxin CARDS inhibited the cell $\mathrm{H}_{2} \mathrm{O}_{2}$ enzyme to cause oxidative damage, cause host cell vacuolation, and induce cell apoptosis (Almagor et al., 1984; Kannan and Baseman, 2006). This is followed by the activation of the immune system, including toll-like receptor excitation in the cell membrane (Naghib et al., 2018), which triggers a cascade of protein signals downstream. We have a reason to believe that these receptors recognize MP through pathogen-associated molecular patterns and endogenous damage-associated molecular patterns. On the one hand, the receptors trigger the body's metabolic disorder. On the other hand, they induce the expression of pro-inflammatory factors, cause inflammatory infiltration, and recruit white blood cells to induce inflammation (Karimi and Arababadi, 2014; Naghib et al., 2018; Hsieh et al., 2020). By changing the levels of cytokines, MPP can significantly change Th1/Th2 levels (Yang et al., 2019). Current research supports these claims and explains the causes of extrapulmonary symptoms. MPP is always like a hidden ghost trying to avoid activating the innate immune system (Merrell and Falkow, 2004). This is related to its destructiveness and structure. It also reflects the fact that asymptomatic infections of MPP account for the majority of cases (Bajantri et al., 2018), but the proportion of hospitalized patients and the mortality rate is gradually increasing (Khoury et al., 2016). The symptoms of MPP patients are mostly respiratory diseases, accompanied by flu-like symptoms such as fever, headache, cough, and muscle aches. There are often pulmonary rales and lung base dullness (Kumar, 2018). In severe cases, it leads to diffuse pneumonia, respiratory distress syndrome, etc. (Kannan et al., 2012). Because of the influence of inflammatory factors of the dimer of complement and fibrin-D, it causes long-lasting immune damage and causes vasculitis, which leads to thrombosis. This change will affect the entire body and cause harm including encephalitis (Lin et al., 2014). MP secretion stimulates the ganglia to cause permanent damage to the peripheral nervous system and central nervous system (Narita, 2009).

To treat MPP, clinically effective macrolides are commonly used (Blyth and Gerber, 2018). However, mild patients and children should try to avoid antibiotics. In East Asia, the drug resistance rate of macrolides is increasing year by year (Liu et al., 2009; Zhou et al., 2014; Yamazaki and Kenri, 2016; Yang et al., 2017). Research on the resistance of lactams is also ongoing (Purba et al., 2019; Liu et al., 2020).

Traditional Chinese medicine is guided by the theories of traditional Chinese medicine, which is widely used in East Asia and Southeast Asia and has outstanding efficacy (Li, 2020). Qinbaiqingfei concentrated pills are made by Baikal skullcap (Pharmacopoeia of China 2015), Pheretima (Pharmacopoeia of China 2020), Stemonae Radix (Pharmacopoeia of China 2015), Asteris Radix et Rhizoma (Pharmacopoeia of China 2015), Ophiopogon (US FDA Substance Registration System 2016) and Platycodonis Radix (Pharmacopoeia of China 2015). It is the first traditional medicine approved by the Chinese government for the clinical treatment of mycoplasma pneumonia (2004 L04185). We have confirmed that baicalin and platycodin D in QB is produced by inhibiting MP adhesin protein $\mathrm{P} 1$ and acting on the epidermal growth factor.
Antimycoplasma ability and excellent tissue repair function (Meng et al., 2012; Meng et al., 2014; Meng et al., 2017). However, our focus is always on specific points of action. This kind of inquiry is not suitable for initial research on natural medicines. Using systemic pharmacology and preliminary research, medicine is also a focus of our scientific research.

Although advances in technology have helped us discover countless new disease targets, we still face the agony of many diseases and are powerless to prevent them. Explaining the mechanism of action of complex drugs is always a difficult subject. Combined with biomarker screening, pharmacodynamics, and pharmacokinetics, research has become a direction of our current concern (Collis, 2006). Firstly, we use pathological slices and an inflammation level detector to evaluate the efficacy. Secondly, the UPLC-Q/TOFMS technology is used to perform untargeted identification and analysis of the collected samples, explaining the potential interactions between various endogenous metabolic processes and exogenous effects of diseases or drug treatments. To analyze the changes of biomarkers, find out interpreting the biological significance of the potentially affected biomarkers (Qian et al., 2018). Network pharmacology can be used to predict the correlation between targets and indications. The molecular docking technology that simulates the molecular structure at the molecular level and the dynamic level verifies the binding status between the targets (Tang et al., 2020). Through the integrated analysis of them, we explore its mechanism of action in the treatment of mycoplasma pneumonia. Figure 1.

\section{MATERIALS AND METHODS}

\section{Ethical Approval}

This study was reviewed by the Ethics Committee of the Heilongjiang Academy of Chinese Medicine Sciences (No. 2015-64) and the experiments were conducted by the Chinese Government's "Guidelines on the Care and Use of Laboratory Animals" to minimize their suffering.

\section{Reagents and Materials}

Reagents included Qinbaiqingfei concentrated pills (Heilongjiang Academy of Chinese Medicine, 20200715 China), azithromycin (Pfizer, United States), methanol, acetonitrile (chromatography pure, Merck, Germany), formic acid (chromatography pure, Fisher, United States), distilled water (Watsons, China), methanol, acetonitrile (analysis of pure, Kemiou, China), the rat serum IL-10, TNF- $\alpha$ ELISA kit (Boster, China), mycoplasma pneumoniae nucleic acid detection kit (Da-an gene, China), NF$\kappa \mathrm{B}$ p65 rabbit polyclonal antibody, IKK- $\alpha$ rabbit polyclonal antibody, IKB- $\alpha$ rabbit polyclonal antibody, MyD88 rabbit polyclonal antibody, $\beta$-actin antibody, and horseradish peroxidase-labeled goat anti-rabbit IgG $(\mathrm{H}+\mathrm{L})$ (Beyotime Biotechnology, China).

Materials included Acquity UPLC (Waters, United States, including binary high-pressure gradient pump, vacuum degasser, autosampler, and column oven), AB SCIEX Triple- 


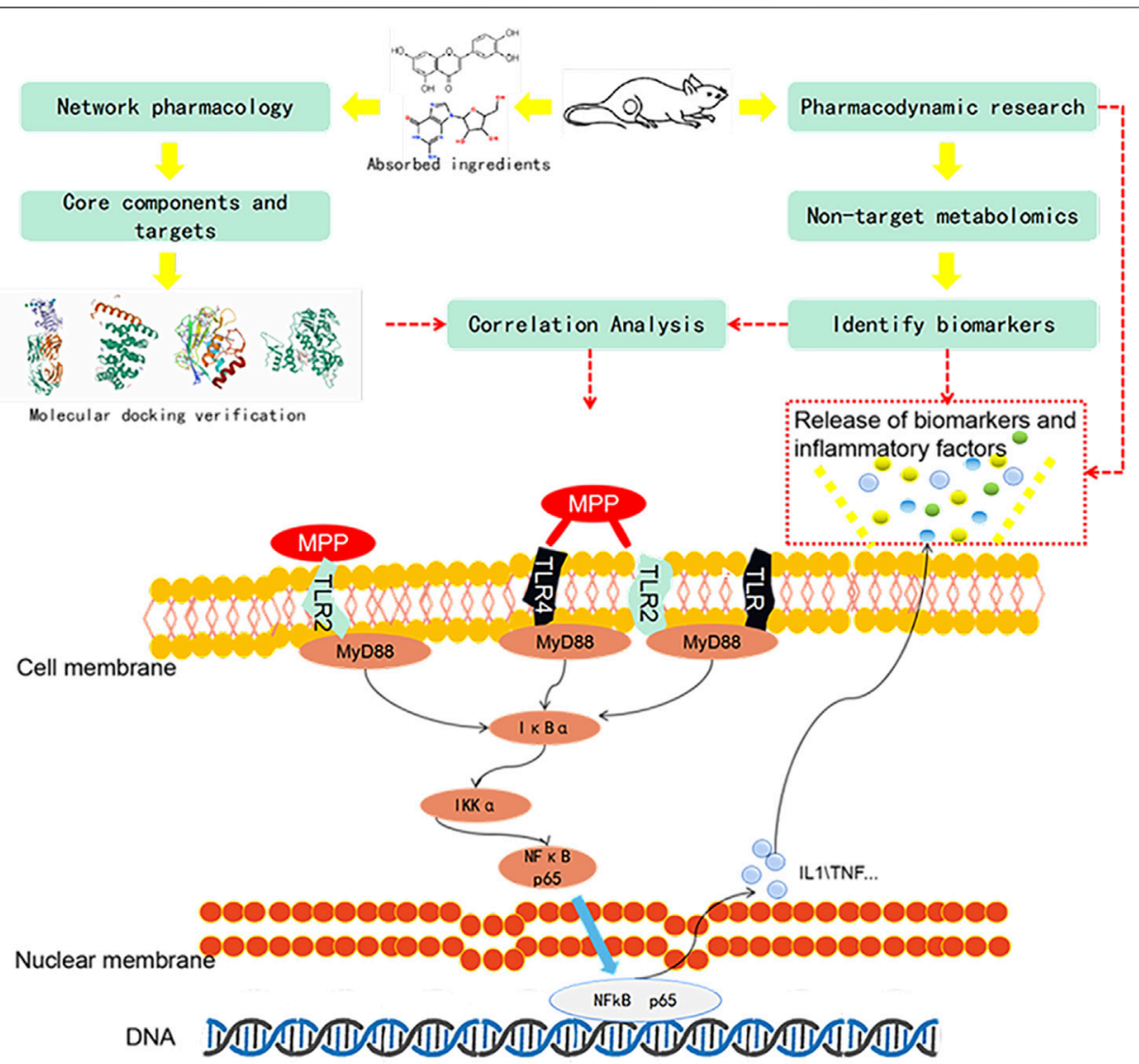

FIGURE 1 | Process design diagram.

TOFTM $5600^{+}$mass spectrometer (AB SCIEX, United States, equipped with ESI Source and APCI source), data acquisition software was analyst TF 1.6 software (AB SCIEX, United States), data processing software system: Peakview 2.0/masterview1.0 software (AB SCIEX, United States), Progenesis QI 2.0 software (Waters, United States), Waters Acquity UPLC BEH $\mathrm{C}_{18}$ column $(1.7 \mu \mathrm{m}, 2.1 \mathrm{~mm} \times 100 \mathrm{~mm})$, Aquity UPLC BEH $\mathrm{C}_{18}$ VanGuard Pre-Column $(1.7 \mu \mathrm{m}, 2.1 \mathrm{~mm} \times 5 \mathrm{~mm})$, Bioer Line gene 9600 fluorescence Quantitative PCR instrument (Hangzhou Bioeri, China), Infinite M200 PRO (Tecan, Switzerland), Orthopolar photographic microscope (Nikon, Japan), and Amersham Imagery 600 gel imaging system (GE Company, United States).

\section{Experimental Animals}

60 SPF Waster rats were raised in a constant temperature and humid environment. After 7 days of adaptive rearing, the rats were randomly divided into groups. Rats were anesthetized with pentobarbital during model building. Using the blind insertion method, the left lung cannula was inserted through the mouth and trachea to inject $200 \mu \mathrm{l}$ of mycoplasma bacterial solution. The control group $(\mathrm{CN})$ was injected with the same amount of sterile culture medium. For the next 6 days, the model was maintained by a $200 \mu \mathrm{l}$ nasal drip after ether anesthesia every day. After modeling, the QB low-dose group $(\mathrm{L})(0.8 \mathrm{~g} / \mathrm{kg})$ was administered intragastrically for 14 days, the QB medium-dose group (M) $(1.6 \mathrm{~g} / \mathrm{kg})$, for 14 days and the $\mathrm{QB}$ high-dose group $(\mathrm{H})$ $(3.2 \mathrm{~g} / \mathrm{kg})$, for 14 days, and the azithromycin group (AZM) ( $45 \mathrm{mg} / \mathrm{kg}$ on the first day, $22.5 \mathrm{mg} / \mathrm{kg}$ ), for 10 days. AZM and $\mathrm{M}$ correspond to adult doses. The adult dose of $\mathrm{QB}$ is $18 \mathrm{~g} / \mathrm{d}$, and the rat dose is calculated by the body surface area method. CN and MPP were given the same dose of purified water daily. On the last day, the rat's urine was collected in a metabolic cage and then anesthetized with pentobarbital. The blood was taken from the abdominal aorta, and the supernatant was centrifuged after standing. The lung tissue was washed with normal saline, and the lower lobe of the right lung was fixed in formalin. Inside, the rest of the tissue is frozen in an ultra-low temperature refrigerator.

10 SPF Waster rats were reared in a constant temperature and humid environment. After being adaptively reared for 7 days, the rats were randomly divided into five groups. QB was given by intragastric administration at $16.2 \mathrm{~g} / \mathrm{kg}$, and $\mathrm{CN}$ was given equal volume of purified water. $1 \mathrm{~h}$ later, the rats were anesthetized with pentobarbital. Blood was collected from the hepatic portal vein and centrifuged, and the supernatant was frozen and stored. The lung tissue was washed and frozen. 


\section{PCR Amplification of Mycoplasma}

Take $100 \mathrm{mg}$ rat lung tissue, add $100 \mu \mathrm{l}$ of water to homogenize for $2 \mathrm{~min}$, centrifuge at $6500 \mathrm{rpm}$ for $10 \mathrm{~min}$, take the supernatant, centrifuge at $12,000 \mathrm{rpm}$ for $5 \mathrm{~min}$, add $50 \mu \mathrm{l}$ DNA extracted from the pellet, treat with $100^{\circ} \mathrm{C}$ for $10 \mathrm{~min}$, centrifuge at $12,000 \mathrm{rpm}$ for $10 \mathrm{~min}$, and add $2 \mu \mathrm{l}$ of the supernatant to the reaction tube. The amplification conditions were $93^{\circ} \mathrm{C}-2 \mathrm{~min} ; 93^{\circ} \mathrm{C}, 45 \mathrm{~s}-55^{\circ} \mathrm{C}, 60 \mathrm{~s}, 10$ cycles; and $93^{\circ} \mathrm{C} 30 \mathrm{~s}$ $-55^{\circ} \mathrm{C} 45 \mathrm{~s}, 30$ cycles.

\section{Pathological Treatment}

The fixed lung tissue was washed with distilled water and dehydrated with ethanol gradient. Xylene was transparently treated twice, soaked in wax, and embedded in a paraffin embedding machine. The embedded tissue was fixed on a microtome for sectioning and placed on a clean carrier. On the glass slides, the slides are dried in a $60^{\circ} \mathrm{C}$ constant temperature oven, and then dewaxed, HE stained, dehydrated, and finally sealed with neutral gum.

\section{Biochemical Index Detection}

After the rat serum was thawed, it was centrifuged at $2000 \mathrm{rpm}$ for $10 \mathrm{~min}$. The supernatant was taken for ELISA detection, and a microplate reader was used for detection.

\section{UPLC-Q/TOF-MS Sample Processing}

Freeze urine samples are gradually heated and thawed; take $200 \mu \mathrm{l}$ of urine, add $200 \mu \mathrm{l}$ of distilled water, vortex and centrifuge at $4^{\circ} \mathrm{C}$, $13,000 \mathrm{r} / \mathrm{min}$ for $10 \mathrm{~min}$, and take the supernatant. Take $200 \mu \mathrm{l}$ of the serum, add $800 \mu \mathrm{l}$ of methanol (precooled at $-20^{\circ} \mathrm{C}$ ), vortex for $2 \mathrm{~min}$, let it stand for $10 \mathrm{~min}$, and centrifuge at $4^{\circ} \mathrm{C}, 13,000 \mathrm{r} /$ min, $10 \mathrm{~min}$. Take $800 \mu \mathrm{l}$ of the supernatant, blow dry with nitrogen, add $200 \mu \mathrm{l}$ of $80 \%$ methanol (precooled at $-20^{\circ} \mathrm{C}$ ) to reconstitute, vortex for $2 \mathrm{~min}, 4^{\circ} \mathrm{C}, 13,000 \mathrm{r} / \mathrm{min}$, centrifuge for $10 \mathrm{~min}$, and take the supernatant to obtain. Take $50 \mathrm{mg}$ of the lung tissue, add $0.25 \mathrm{ml}$ of water for $2 \mathrm{~min}$, add $1.5 \mathrm{ml}$ of methanol: acetonitrile (1:1), vortex for $2 \mathrm{~min}$, ultrasound for $2 \mathrm{~min}$, and allow it to stand for $10 \mathrm{~min}$. Then, take $1 \mathrm{ml}$ of the supernatant and centrifuge at $13,000 \mathrm{r} / \mathrm{min}$ for $10 \mathrm{~min}$ at $4^{\circ} \mathrm{C}$, take $800 \mu \mathrm{l}$ of the supernatant and dry it with nitrogen. Then, reconstitute it with $200 \mu \mathrm{l}$ of $80 \%$ methanol, centrifuge at high speed, and collect the supernatant. Take a small amount of urine, serum, and lung tissue samples from each to make QC samples.

\section{Serum Pharmaceutical UPLC-Q/TOF-MS Sample Preparation}

Take $400 \mu$ of the rat blank serum and administration serum, add $10 \mu \mathrm{l}$ of phosphoric acid to each, vortex for $60 \mathrm{~s}$, add $2.4 \mathrm{ml}$ methanol, vortex for $60 \mathrm{~s}$ at $4^{\circ} \mathrm{C}, 13,000 \mathrm{rpm}$ for $10 \mathrm{~min}$, blow-dry the supernatant with nitrogen and reconstitute the residue with $200 \mu \mathrm{l}$ of methanol, vortex and shake for $60 \mathrm{~s}$, and centrifuge at $13,000 \mathrm{rpm}, 4^{\circ} \mathrm{C}$ for $10 \mathrm{~min}$. Then, take the supernatant for UPLC-Q/TOF-MS analysis. Take $100 \mathrm{mg}$ of the lung tissue, add $1 \mathrm{ml}$ water, homogenize for $3 \mathrm{~min}$, add $10 \mu \mathrm{l}$ of phosphoric acid and vortex for $60 \mathrm{~s}$, add $4 \mathrm{ml}$ acetonitrile, vortex for $2 \mathrm{~min}$, allow it to stand for $10 \mathrm{~min}$, and centrifuge at $4^{\circ} \mathrm{C}$, $13,000 \mathrm{rpm}$ for $10 \mathrm{~min}$.

\section{Mass Spectrometry Conditions}

Adopt an ESI ion source, the ionization mode is electric spray positive and negative ion mode, the positive and negative ion source voltage is $5500 \mathrm{~V} /-4500 \mathrm{~V}$, ion source temperature is $550^{\circ} \mathrm{C}$, cleavage voltage is $100 \mathrm{~V} /-100 \mathrm{~V}$, collision energy are $35 \mathrm{eV} /-35 \mathrm{eV}$, and collision energy extension are $15 \mathrm{eV} /$ $-15 \mathrm{eV}$. The atomizing gas is nitrogen, the auxiliary gas Gas1 is 55 PSI, the auxiliary gas Gas2 is 55 PSI, and the curtain gas CurGas is 35 PSI. The scanning range of the precursor ion of the primary mass spectrum is $80-1200 \mathrm{Da}$. IDA sets the eight highest peaks with a response value of over $100 \mathrm{cps}$ to scan the secondary mass spectrum; the scanning range of the product ion is 50-1200 Da, and dynamic background subtraction is enabled.

\section{The Chromatographic Conditions}

Column temperature: $35^{\circ} \mathrm{C}$; mobile phase: A: $0.1 \%$ formic acid water and B: $0.1 \%$ formic acid acetonitrile. The gradient elution sequence is as follows and only write the proportion of $\mathrm{B}$. Urine: $5-45 \%$ from 0 to $16 \mathrm{~min}, 45-100 \%$ from 16 to $18 \mathrm{~min}$, and $5 \%$ from 18.1 to $20 \mathrm{~min}$. Serum: $5-55 \%$ from 0 to $5 \mathrm{~min}, 55-65 \%$ from 5 to $9 \mathrm{~min}, 65-75 \%$ from 9 to $13 \mathrm{~min}, 75-100 \%$ from 13 to $18 \mathrm{~min}$, and $5 \%$ from 18.1 to $20 \mathrm{~min}$. Lung tissue: $5-55 \%$ from 0 to $3 \mathrm{~min}, 55-65 \%$ from 3 to $6 \mathrm{~min}, 65 \%$ from 6 to $8 \mathrm{~min}, 65-70 \%$ from 8 to $10 \mathrm{~min}, 70-100 \%$ from 10 to $18 \mathrm{~min}$, and $5 \%$ from 18.1 to $20 \mathrm{~min}$. Blood components: $5-55 \%$ from 0 to $5 \mathrm{~min}, 55-65 \%$ from 5 to $9 \mathrm{~min}, 65-75 \%$ from 9 to $13 \mathrm{~min}, 75-100 \%$ from 13 to $18 \mathrm{~min} \mathrm{~s}$, and $5 \%$ from 18.1 to $20 \mathrm{~min}$. Lung component: $5-55 \%$ from 0 to $3 \mathrm{~min}, 55-65 \%$ from 3 to $6 \mathrm{~min}, 65 \%$ from 6 to $8 \mathrm{~min}$, $65-70 \%$ from 8 to $10 \mathrm{~min}, 70-100 \%$ from 13 to $18 \mathrm{~min}$, and $5 \%$ from 18.1 to $20 \mathrm{~min}$. The flow rate is $0.3 \mathrm{ml} / \mathrm{min}$ and the injection volume is $5 \mu \mathrm{l}$.

\section{Liquid and Mass Data Processing}

Import the collected metabolic profile data onto Progenesis QI software, and go through peak matching, peak extraction, normalization, data dimension reduction, and mass spectrum matrix information acquisition. Establish the variable projection importance VIP file. Select VIP $>1$ variables as potential biomarkers preliminary screening for these potential markers, further analysis of the trend of changes in the content of these potential markers for the sample. The second potential marker screening is performed based on the principle of significant differences in metabolites between groups $(p<0.05)$ to obtain potential biomarkers things. In this experiment, we first screened between the control group and the MPP group and preliminarily screened based on the principles of VIP $>1$ and $p<0.05$. Then, we reviewed the initially selected compounds with the administration group to initially determine the difference.

Use the Masterview function in Peakview2.0 software to import the liquid quality acquisition data of the administered serum and the blank serum. Set the mass error $<5 \mathrm{ppm}$; weight $30 \%$, isotope difference $<10 \%$; weight $40 \%$, Formula finder score $>70 \%$; weight $40 \%$, sample/control is three times to deduct the interference of the blank serum endogenous components. 
Compare the remaining detected ions with the retention time, isotope kurtosis ratio, the accurate mass of the precursor ion, and the secondary mass spectrum of the compound detected in the extract of QB. If they are consistent, it is confirmed as the prototype component in $\mathrm{QB}$.

\section{Component Targets and Disease Screening} Target screening of the obtained ingredients, in SwissTargetPrediction (principle: ligand structure similarity), DrugBank (principle: ligand structure similarity), PharmMapper (principle: pharmacophore matching), and BATMAN-TCM (principle: query component Possible component target interactions and the similarity of component target interactions known in the database). Set Probability $\geq 0.70$ in SwissTargetPrediction, select "Homo sapiens" in "Choose an organism." Select " 0.70 " in "Similarity threshold" in DrugBank, set " 20 " in BATMAN-TCM "Score cutoff," and NormFit $\geq 0.70$ in PharmMapper to get the final possible target.

In the eight databases of NCBI Gene, DrugBank, GeneCards, DisGeNET, TTD, PharmGKB, OMIM, and KEGG, search with "Pneumonia" and "Mycoplasma pneumonia" as keywords. In addition, the relevant gene chips were retrieved in GEO with "Pneumonia" and "Mycoplasma pneumonia" as keywords, and impute package v1.62.0 and limma package v3.44.3 of R v4.0.0 were used to impute missing values. Standardize processing and pass experience Bayesian model is used to determine the differential gene, and the differential gene threshold is set to $p<0.05$ and $\mid \log 2$ fold change $\mid \geq 1$. In order to ensure the accuracy of disease target prediction, the disease targets of the abovementioned sources are intersected to obtain the disease target and the intersection target is obtained.

\section{C-T Network and T-D Network Construction and Topology Analysis}

The contribution of the components to the C-T network is evaluated by introducing the Contribution Index. The PubMed search strategy is to use "Pneumonia" and "Mycoplasma pneumonia" in the Abstract/Title section. The English name of the active ingredient on the Internet and the commonly used keywords are jointly searched for documents from 1990 to December 1, 2020. Build a C-T network through screening.

The T-D network obtains the interaction between them through STRING. Set "organism" and "minimum required interaction score" to "Homo sapiens" and "medium confidence (>0.400)." Construct a T-D network by importing Cytoscape. Combine coreness, closeness, degree, average shortest path length, and betweenness to judge the importance of nodes. The filter condition is first $>$ the mean degree. Then, it meets the mean values of degree, closeness, betweenness, and coreness at the same time and less than the mean value of the average shortest path length.

\section{Molecular Docking}

For molecular docking of the core target and core components, use GEMDOCK and select "200," "Population size," "Generation," "Number of solutions," and "Default setting" in the software operation interface. "Docking Accuracy Settings." "7," "2," and "Docking standard," the other docking parameters, are all default.

\section{Biomarker and Core Target Enrichment Analysis}

Using Progenesis QI 2.0 software, import the experimentally obtained disease treatment targets and biomarkers with significant callback effects to http://impala.molgen.mpg.de/ for comprehensive molecular pathway level analysis. Analyze genes and metabolites that carry out integration and association. Through the screening of the $p$ value and $\mathrm{Q}$ value, the path with biological significance is screened to the limit of satisfying $p<0.05$ and $\mathrm{Q}<0.05$ at the same time.

\section{Protein Expression Detection of Core Pathways}

Take $50 \mathrm{mg}$ of the rat lung tissue, add $500 \mu \mathrm{l}$ of PBS and homogenize on ice bath, and centrifuge at $500 \mathrm{~g}$ for $3 \mathrm{~min}$. Remove the supernatant, add $100 \mu \mathrm{l}$ of the nucleoprotein extraction reagent and extract and centrifuge, take the supernatant, and add the loading buffer. It can be pyrolyzed and stored in aliquots. Prepare a separation gel and concentrated gel (accelerating coagulation at $37^{\circ} \mathrm{C}$ ) in accordance with the requirements of the kit and load a small amount of the sample. Then use $80 \mathrm{mV}$ for concentrated gel separation, $120 \mathrm{mV}$ for separation gel separation, and $200 \mathrm{~mA}, 1.5 \mathrm{~h}$ for $\mathrm{CN}$ membrane transfer and membrane washing. It is then blocked with $5 \%$ skim milk for $0.5 \mathrm{~h}$, blocked with the primary antibody overnight, and incubated with the secondary antibody for $2 \mathrm{~h}$. After washing the membrane, add luminescent solution to take pictures.

\section{RESULTS}

\section{The Amount of Mycoplasma Detected by RT-PCR}

The amount of mycoplasma in rats in the MPP group reached $1.15 \times \mathrm{e}^{7}$. Both the $\mathrm{QB}$ and $\mathrm{AZM}$ groups decreased, which was below the minimum detection limit of the kit (Figure 2A). In this case, it can be considered that there is no infectious ability.

\section{Histopathological Analysis}

A representative photomicrograph of HE staining is shown in Figure 3B. In the control group, the surface of the lung tissue was smooth and the alveolar wall structure was clear. In the pneumonia group, alveolar walls were thickened and eosinophils were occasionally increased. There are some foam cells and the inflammatory infiltration near the blood vessels forms a ring. These two conditions indicate that this has caused damage to the vascular structure. Both $\mathrm{QB}$ and AZM alveolar wall thickness decreased, and alveolar stenosis 


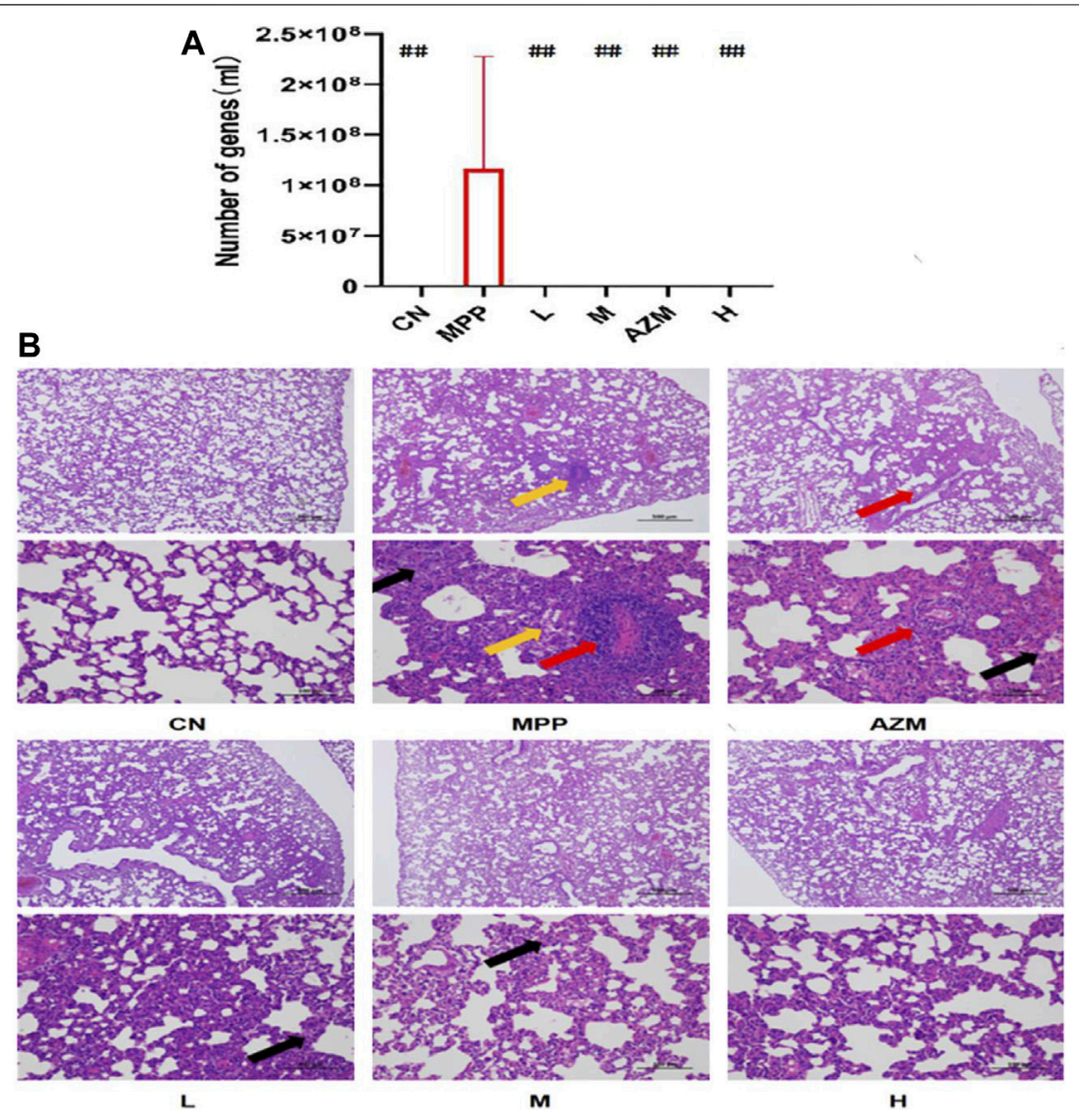

FIGURE 2 | HE staining of rat lung tissue and the amount of mycoplasma carrier in lung tissue. (A) RtPCR mycoplasma real-time fluorescence detection, using analysis of variance to calculate the significant difference, compared with the MPP group $\# p<0.05$, \#\#p $<0.01$. (B) The alveolar wall of the control group was composed of a single layer of epithelium with a simple structure; the interstitium, including the connective tissue and blood vessels in the lung, had no obvious abnormalities. In the Mycoplasma pneumoniae group, large areas of alveolar walls are severely thickened, alveolar sizes vary, alveolar walls are infiltrated with a large number of inflammatory cells (black arrows), and few of the foam cells in the alveolar cavity (yellow arrows) and local perivascular inflammatory cells infiltrate into rings (red arrow). In the QB group, the alveolar wall was slightly thickened, with a small amount of inflammatory cell infiltration in the alveolar wall (black arrow). In the AZM group, large areas of alveolar walls were moderately thickened, alveolar sizes varied, and alveolar walls were infiltrated with moderate inflammatory cells (black arrows).

was not seen. The QB group recovered better, with tissue fluid exudation and inflammatory infiltration significantly contracted. This is related to its composition. We have confirmed that QB has good tissue repair ability (Meng et al., 2014), which is a unique advantage over AZM.

\section{Biochemical Index Determination}

Using IL-10, TNF- $\alpha$, and Th1/Th2 ratios as evaluation indicators (Figure 3A), the MPP, CN, QB, and AZM groups were collected to evaluate the effect of QB on MPP. Compared with the control group, the levels of IL-10 and TNF- $\alpha$ in the MPP group were significantly increased. The Th1/Th2 ratio showed an upward trend $(p<0.01)$. After QB and AZM treatment, the above indicators recovered (Figure 3B). It should be noted that the Th1/Th2 ratio is higher in the control group than in the pneumonia group, but IL-10 also has a rising trend in the MPP group. The differentiation of Th0 cells depends on the expression of the transcription factors T-bet and GATA-3
(Tibbitt et al., 2019). In the early stage of the disease, there is a Th1 advantage (Wu et al., 2019). With the development of the disease, the activation of innate immunity requires the activation of Th2 cells and is used to deactivate the precursor of IgE (Wynn, 2015). At the same time, it promotes the secretion of eosinophils, airway hyperresponsiveness, and mucus production (Hamilos, 2015). As a sensitizing inflammatory factor, long-term high expression of Th2 can not only inhibit the inflammatory response but also cause allergic tissue damage (Tibbitt et al., 2019). Th2 dominance exists in the later stage of the disease, as a means for the body to resist foreign invasion (Koh et al., 2001).

\section{Metabolic Profile Analysis}

By constructing the OPLS-DA diagram, it is found that QB and MPP are well separated. QB and AZM are well separated from the MPP group and tend to be close to the CN group (Figure 4). MetaboAnalyst screened 105 compounds, and 56 were dosing callbacks (Table 1 and Figure 5). 

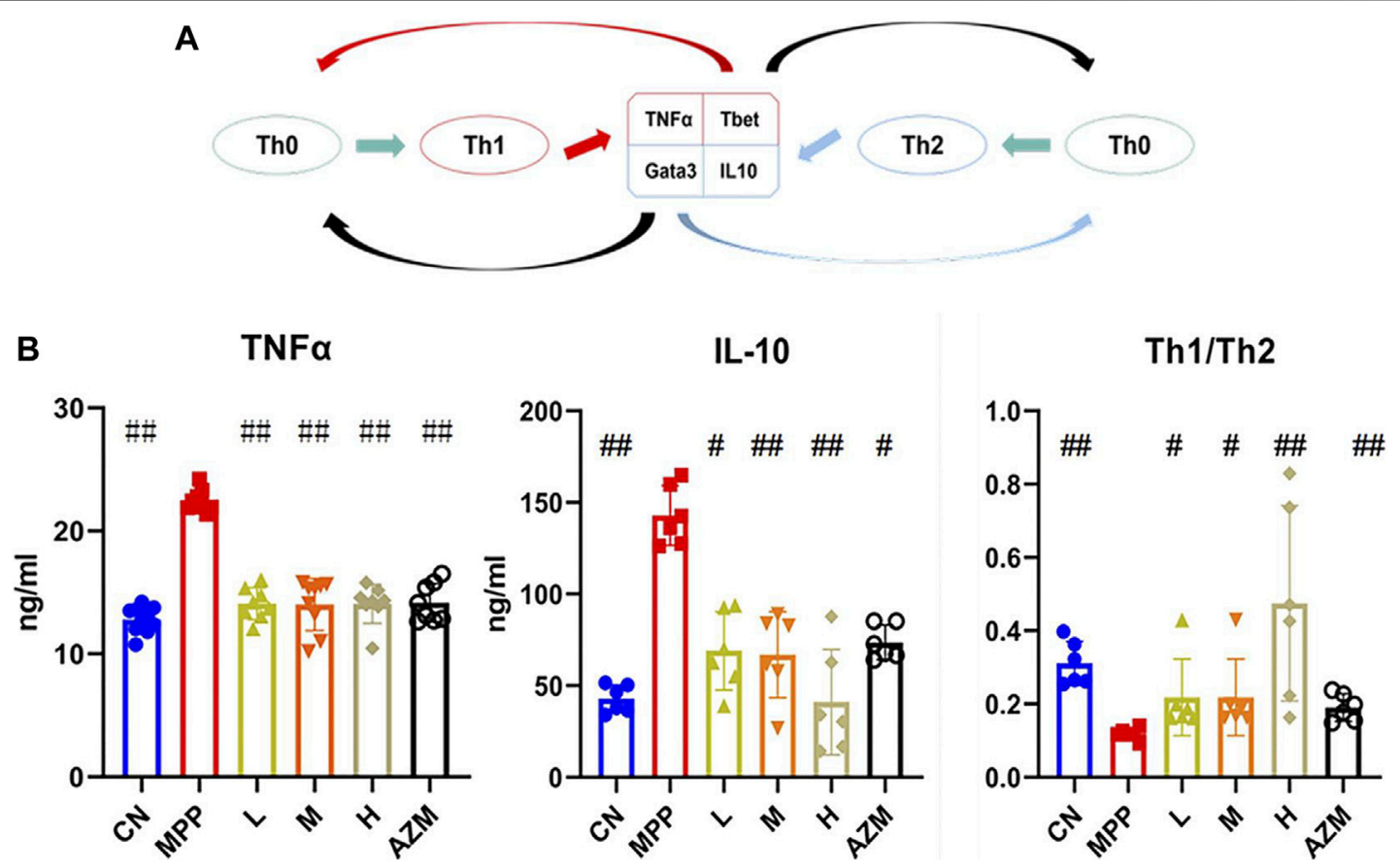

FIGURE 3 | (A) T-cell differentiation diagram, the black arrow indicates inhibition and the remaining arrows indicate promotion. (B) Serum TNF- $\alpha$ and IL-10 expression levels, and the Th1/Th2 ratio. The significant difference was calculated using analysis of variance, \#p $<0.05$, \#\#p $<0.01$ and compared with the MPP group.

\section{UPLC-Q/TOF-MS Data of Lung Tissue and Serum}

Data collection of the rat serum and lung tissue was conducted, and 31 prototype components belonging to Qinbaiqingfei concentrated pills were identified. The results are shown in Table 2.

\section{Inference of Typical Compound Cleavage Law}

The components that enter the lungs and blood are mostly flavonoids and alkaloids. Flavonoids and alkaloids have strong effects of inhibiting microorganisms, antioxidation, antiinflammatory, protecting blood vessels, and neuroprotection (Birt et al., 2001; Parnell et al., 2012; Meng et al., 2014; Xie F. et al., 2020; Ku et al., 2020; Rui et al., 2020; Porras et al., 2021). Take the flavonoid "wogonin" and the alkaloid "tuberostemoninol A" as examples to illustrate the identification process.

The wogonin quasi-molecular ion is $\mathrm{m} / \mathrm{z} 285[\mathrm{M}+\mathrm{H}]^{+}$. This fragment has a relatively high abundance, and the fragmentation is divided into three ways. The quasi-molecular ion A-ring removes the methyl group attached to the methoxy group, and the oxygen forms at one end of the ion to form an end that connects to the benzene ring. Another cleavage pathway is the combination of the hydroxyl group of the A-ring and the methyl hydrogen to remove a molecule of water, and the remaining ethyl group will then fall off to form the fragment ion of $\mathrm{m} / \mathrm{z} 253$. Continue to remove the carbonyl group to form $\mathrm{m} / \mathrm{z} 225$ fragment ions. The third way is that under the bombardment of high- energy particles, the A-ring is connected with the methoxy group and the hydroxyl group to break off the carbon atoms to form a ring-opening rearrangement to form $\mathrm{m} / \mathrm{z} 213$ fragment ions and continue to deoxidize to form $\mathrm{m} / \mathrm{z} 197$ fragment ions or directly remove the B-ring benzene ring to form $\mathrm{m} / \mathrm{z} 137$ fragments. The specific cracking method is shown in Figure 6A.

The cleavage of tuberostemoninol A is relatively simple. The two ways are first to continuously remove $\mathrm{H}_{2} \mathrm{O}$ and $\mathrm{CO}$ to form $\mathrm{m} / \mathrm{z} 388$ and $\mathrm{m} / \mathrm{z} 360$ fragment ions. The other is to remove two carbon rings to form $\mathrm{m} / \mathrm{z} 200$ rearranged ions, and continue to remove water molecules to form $\mathrm{m} / \mathrm{z} 182$ fragment ions. The specific cracking method is shown in Figure 6B.

\section{Target Analysis}

414 (Four hundred and fourteen) component targets were obtained by predicting the component targets of the four databases. And one related gene chip was retrieved from the database (Chen JW. et al., 2020): GSE40012 is provided by the Intensive Care Lab of the Nepean Clinical School of University of Sydney, Kingswood, NSW, Australia. The chip contains 190 gene expression data sets of influenza pneumonia patients, bacterial pneumonia patients, mixed bacterial and influenza pneumonia patients, systemic inflammatory response patients, and healthy control. We selected 61 cases of bacterial pneumonia patients and 36 cases of healthy control, a total of 97 cases for research. Use impute package v1.62.0 and limma package v3.44.3 of R v4.0.0 to impute missing values, standardize, and determine differential genes through empirical Bayesian models. The threshold of differential genes is set to $p<0.05$ and $\mid \log 2$ fold change $\mid \geq 1$. To ensure the accuracy of disease target prediction, the disease 

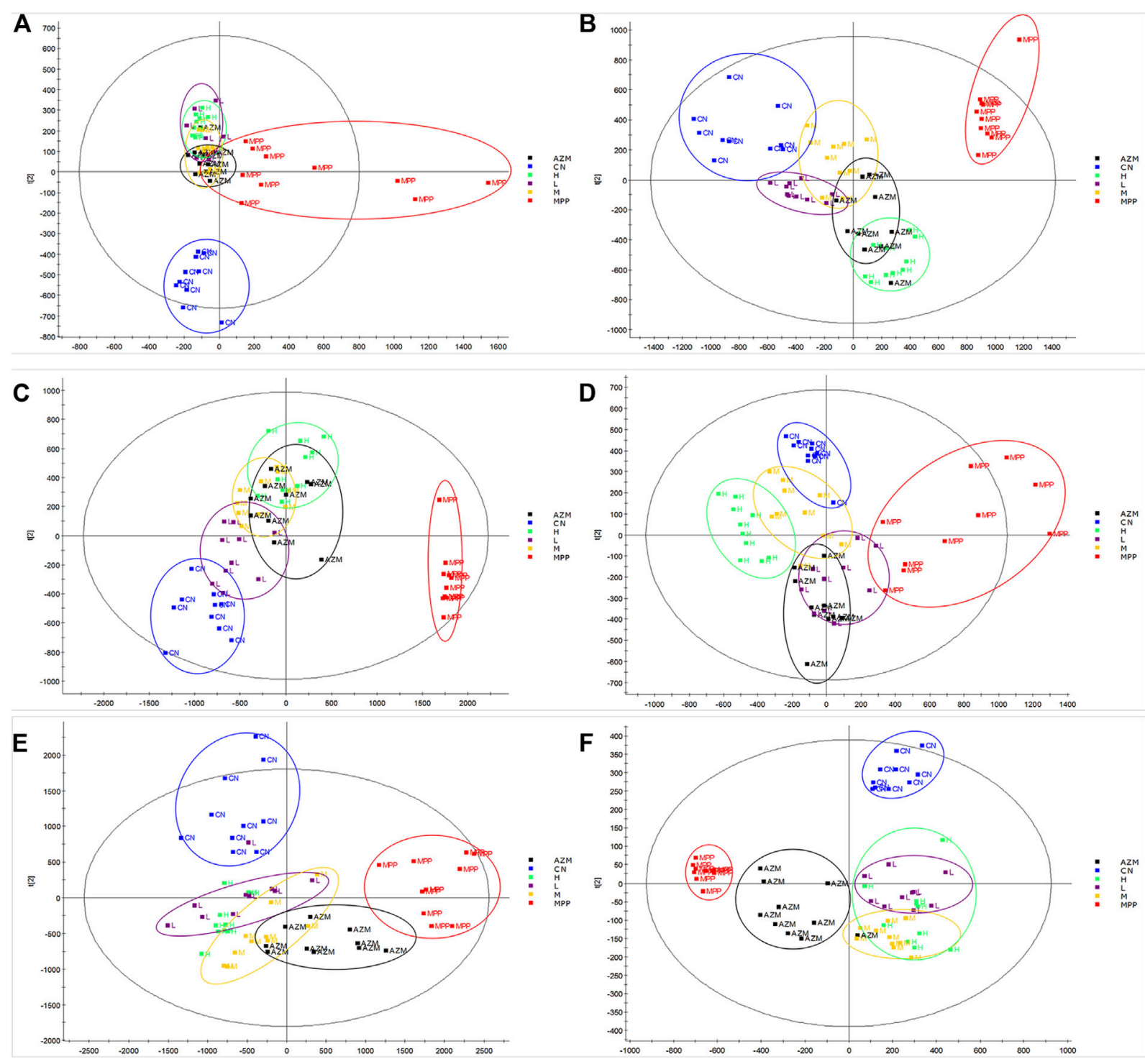

FIGURE 4 | Urine, serum, and lung tissue OPLS-DA images of rats in CN, MPP, QB, and AZM groups. (A) Four groups of urine positive ion mode OPLS-DA diagram (B) Four groups of urine negative ion mode OPLS-DA diagram (C) Four groups of serum positive ion mode OPLS-DA diagram (D) Four groups of serum negative ion mode OPLS-DA diagram (E) Four groups of lung tissues with positive ion mode OPLS-DA (F) four groups of lung tissues with negative ion mode OPLS-DA. We select 10 samples for each group.

targets from the above sources were obtained by intersecting the disease targets, and 778 targets were obtained. Finally, the component targets and disease targets were re-intersected. Finally, 67 therapeutic targets were obtained (the above retrieval date ended at 2020.12.1).

\section{C-T Network and T-D Network and Topology Analysis}

After the C-T network deletes the isolated nodes and their connected edges, there is a total of 89 nodes, representing 22 compound components and 67 therapeutic targets; 129 edges represent 129 component-target relationships (Figure 7). The results show that the total CI of luteolin, guanosine, wogonin, and isorhamnetin is $93.79 \%$ (greater than $85 \%$ ), which is the core component that contributes the most to the C-T network.

The T-D network finally screened and obtained six core therapeutic targets: SIRT1, IL-10, MMP9, CTNNB1, CRP, and EGFR (Table 3). The therapeutic target and the interaction relationship between the targets are imported into Cytoscape to construct a T-D network. After deleting the isolated nodes and connected edges, there are 67 nodes and 384 edges in the network (Figure 8A). Extract the target points greater than the mean value of the degree (11.463) to form the core target point network 1. After deleting the isolated nodes and connected edges, there are 25 nodes and 184 edges in the network (Figure 8B). Extract six 
TABLE 1 | Urine, serum, and lung tissue have a tendency to pull back biomarkers.

\begin{tabular}{|c|c|c|c|c|c|c|c|c|}
\hline No & $\begin{array}{l}\text { Retention } \\
\text { time(s) }\end{array}$ & M/S & $\mathbf{M} \pm \mathbf{H}$ & HMDB & $\begin{array}{l}\text { Chemical } \\
\text { formula }\end{array}$ & $\begin{array}{l}\text { Common } \\
\text { name }\end{array}$ & $\begin{array}{l}\text { Sources } \\
\text { and trends }\end{array}$ & $\begin{array}{l}\text { Max fold } \\
\text { change }\end{array}$ \\
\hline 1 & 0.32 & 194.0476 & $\mathrm{M}-\mathrm{H}$ & HMDB01229 & $\mathrm{C}_{9} \mathrm{H}_{9} \mathrm{NO}_{4}$ & Dopaquinone & Serum个\#\# & 6.6435 \\
\hline 2 & 0.41 & 146.0255 & $\mathrm{M}-\mathrm{H}$ & HMDB06779 & $\mathrm{C}_{8} \mathrm{H}_{5} \mathrm{NO}_{2}$ & Indole-5,6-quinone & Serum $\uparrow \# \#$ & 7.7430 \\
\hline 3 & 0.62 & 196.0633 & $\mathrm{M}-\mathrm{H}$ & HMDB00181 & $\mathrm{C}_{9} \mathrm{H}_{11} \mathrm{NO}_{4}$ & L-dopa & Serum $\uparrow \# \#$ & 4.7872 \\
\hline 4 & 0.72 & 190.0523 & $\mathrm{M}-\mathrm{H}, \mathrm{M}+\mathrm{FA}-\mathrm{H}$ & HMDB60400 & $\mathrm{C}_{10} \mathrm{H}_{9} \mathrm{NO}_{3}$ & 5-phenyl-1,3-oxazinane-2,4-dione & Serum $\uparrow \# \#$ & 6.9405 \\
\hline 5 & 0.74 & 182.0480 & $\mathrm{M}-\mathrm{H}$ & HMDB00017 & $\mathrm{C}_{8} \mathrm{H}_{9} \mathrm{NO}_{4}$ & 4-pyridoxic acid & Serum $\uparrow \# \#$ & 5.1829 \\
\hline 6 & 0.92 & 140.0668 & $\mathrm{M}+\mathrm{Na}$ & HMDB00043 & $\mathrm{C}_{5} \mathrm{H}_{11} \mathrm{NO}_{2}$ & Betaine & Serum个\# & 2.3167 \\
\hline 7 & 0.93 & 177.0403 & $\mathrm{M}-\mathrm{H}$ & HMDB03466 & $\mathrm{C}_{6} \mathrm{H}_{10} \mathrm{O}_{6}$ & L-Gulonolactone & Serum $\uparrow \# \#$ & 62.2394 \\
\hline 8 & 0.96 & 167.0209 & $\mathrm{M}-\mathrm{H}$ & HMDB00289 & $\mathrm{C}_{5} \mathrm{H}_{4} \mathrm{~N}_{4} \mathrm{O}_{3}$ & Uric acid & Lung $\uparrow \# \#$ & 2.5697 \\
\hline 9 & 0.97 & 245.0308 & $\mathrm{M}+\mathrm{FA}-\mathrm{H}$ & HMDB01268 & $\mathrm{C}_{8} \mathrm{H}_{8} \mathrm{O}_{6}$ & 4-fumarylacetoacetic acid & Urine $\downarrow \# \#$ & 1.7411 \\
\hline 10 & 1.61 & 150.0571 & $\mathrm{M}+\mathrm{H}$ & HMDB00696 & $\mathrm{C}_{5} \mathrm{H}_{11} \mathrm{NO}_{2} \mathrm{~S}$ & L-Methionine & Serum\\
#\# & 2.6644 \\
\hline 11 & 2.01 & 283.0685 & $\mathrm{M}-\mathrm{H}$ & HMDB00299 & $\mathrm{C}_{10} \mathrm{H}_{12} \mathrm{~N}_{4} \mathrm{O}_{6}$ & Xanthosine & Lung\\
#\# & 3.1764 \\
\hline 12 & 2.09 & 686.1447 & $\mathrm{M}-\mathrm{H}$ & HMDB01373 & $\mathrm{C}_{21} \mathrm{H}_{35} \mathrm{~N}_{7} \mathrm{O}_{13} \mathrm{P}_{2} \mathrm{~S}$ & Dephospho-CoA & Lung\\
#\# & 10.2279 \\
\hline 13 & 2.76 & 228.0876 & $\mathrm{M}+\mathrm{FA}-\mathrm{H}$ & HMDB00819 & $\mathrm{C}_{9} \mathrm{H}_{13} \mathrm{NO}_{3}$ & Normetanephrine & Serum $\uparrow \# \#$ & 2.3080 \\
\hline 14 & 2.85 & 322.9500 & $\mathrm{M}-\mathrm{H}, 2 \mathrm{M}-\mathrm{H}$ & HMDB42049 & $\mathrm{C}_{8} \mathrm{H}_{11} \mathrm{Cl}_{3} \mathrm{O}_{7}$ & Trichloroethanol glucuronide & Lung $\uparrow \# \#$ & 1.7335 \\
\hline 15 & 3.47 & 291.0080 & $\mathrm{M}-\mathrm{H}$ & HMDB60449 & $\mathrm{C}_{7} \mathrm{H}_{15} \mathrm{Cl}_{2} \mathrm{~N}_{2} \mathrm{O}_{4} \mathrm{P}$ & Carboxyphosphamide & Urine $\downarrow \# \#$ & 1.4315 \\
\hline 16 & 3.52 & 295.1261 & $\mathrm{M}-\mathrm{H}$ & HMDB60472 & $\mathrm{C}_{18} \mathrm{H}_{17} \mathrm{FN}_{2} \mathrm{O}$ & Didemethylcitalopram & Urine $\downarrow \#$ & 1.5271 \\
\hline 17 & 3.73 & 192.0665 & $\mathrm{M}-\mathrm{H}$ & HMDB60389 & $\mathrm{C}_{10} \mathrm{H}_{11} \mathrm{NO}_{3}$ & $\begin{array}{l}\text { 4-hydroxy-5-phenyltetrahydro-1,3-oxazin- } \\
\text { 2-one }\end{array}$ & Serum $\uparrow \#$ & 5.2162 \\
\hline 18 & 3.84 & 343.0622 & $\mathrm{M}-\mathrm{H}$ & HMDB02666 & $\mathrm{C}_{12} \mathrm{H}_{17} \mathrm{~N}_{4} \mathrm{O}_{4} \mathrm{PS}$ & Thiamine monophosphate & Urine $\downarrow \# \#$ & 3.0919 \\
\hline 19 & 4.09 & 693.4744 & $\mathrm{M}+\mathrm{FA}-\mathrm{H}$ & HMDB00674 & $\mathrm{C}_{35} \mathrm{H}_{69} \mathrm{O}_{8} \mathrm{P}$ & $\mathrm{PA}(16: 0 / 16: 0)$ & Lung个\#\# & 1.8995 \\
\hline 20 & 5.37 & 583.2534 & $\mathrm{M}+\mathrm{H}, \mathrm{M}+\mathrm{Na}$ & HMDB01008 & $\mathrm{C}_{33} \mathrm{H}_{34} \mathrm{~N}_{4} \mathrm{O}_{6}$ & Biliverdin & Lung $\uparrow \# \#$ & 5.2458 \\
\hline 21 & 5.45 & 391.2129 & $\mathrm{M}+\mathrm{FA}-\mathrm{H}$ & HMDB04030 & $\mathrm{C}_{21} \mathrm{H}_{30} \mathrm{O}_{4}$ & 21-Deoxycortisol & Serum†\#\# & 1.8852 \\
\hline 22 & 5.53 & 488.2968 & $\mathrm{M}+\mathrm{H}, \mathrm{M}+\mathrm{Na}, 2 \mathrm{M}+\mathrm{H}$ & HMDB00138 & $\mathrm{C}_{26} \mathrm{H}_{43} \mathrm{NO}_{6}$ & Glycocholic acid & Serum个\#\# & 3.0544 \\
\hline 23 & 6.09 & 797.6591 & $2 \mathrm{M}-\mathrm{H}$ & HMDB00222 & $\mathrm{C}_{23} \mathrm{H}_{45} \mathrm{NO}_{4}$ & L-Palmitoylcarnitine & Serum个\#\# & 3.4013 \\
\hline 24 & 6.28 & 318.2993 & $\mathrm{M}+\mathrm{H}$ & HMDB04610 & $\mathrm{C}_{18} \mathrm{H}_{39} \mathrm{NO}_{3}$ & Phytosphingosine & Serum个\#\# & 3.4975 \\
\hline 25 & 6.48 & 583.2534 & $\mathrm{M}+\mathrm{H}, \mathrm{M}+\mathrm{Na}$ & HMDB01008 & $\mathrm{C}_{33} \mathrm{H}_{34} \mathrm{~N}_{4} \mathrm{O}_{6}$ & Biliverdin & Serum†\#\# & 6.4105 \\
\hline 26 & 6.50 & 377.1452 & $\mathrm{M}+\mathrm{H}, \mathrm{M}+\mathrm{Na}$ & HMDB00244 & $\mathrm{C}_{17} \mathrm{H}_{20} \mathrm{~N}_{4} \mathrm{O}_{6}$ & Riboflavin & Urine $\uparrow \#$ & 1.7993 \\
\hline 27 & 6.71 & 302.3047 & $\mathrm{M}+\mathrm{H}$ & HMDB00269 & $\mathrm{C}_{18} \mathrm{H}_{39} \mathrm{NO}_{2}$ & Sphinganine & Lung $\uparrow \# \#$ & 2.0649 \\
\hline 28 & 6.74 & 335.2228 & $\mathrm{M}+\mathrm{FA}-\mathrm{H}$ & HMDB03818 & $\mathrm{C}_{19} \mathrm{H}_{30} \mathrm{O}_{2}$ & 5-androstenediol & Lung $\uparrow \#$ & 2.7749 \\
\hline 29 & 6.83 & 395.2439 & $\mathrm{M}+\mathrm{FA}-\mathrm{H}$ & HMDB00268 & $\mathrm{C}_{21} \mathrm{H}_{34} \mathrm{O}_{4}$ & Tetrahydrocorticosterone & Serum $\uparrow \#$ & 20.7376 \\
\hline 30 & 6.96 & 539.0154 & $2 \mathrm{M}-\mathrm{H}$ & HMDB06343 & $\mathrm{C}_{7} \mathrm{H}_{14} \mathrm{~N}_{2} \mathrm{O}_{4} \mathrm{Se}$ & Selenocystathionine & Urine $\downarrow \# \#$ & 4.0243 \\
\hline 31 & 7.30 & 279.2306 & $\mathrm{M}+\mathrm{Na}$ & HMDB00220 & $\mathrm{C}_{16} \mathrm{H}_{32} \mathrm{O}_{2}$ & Palmitic acid & Serum†\#\# & 1.8685 \\
\hline 32 & 7.31 & 279.2312 & $\mathrm{M}+\mathrm{H}$ & HMDB01388 & $\mathrm{C}_{18} \mathrm{H}_{30} \mathrm{O}_{2}$ & Alpha-linolenic acid & Lung $\downarrow \#$ & 3.9947 \\
\hline 33 & 7.40 & 302.3044 & $\mathrm{M}+\mathrm{H}$ & HMDB00269 & $\mathrm{C}_{18} \mathrm{H}_{39} \mathrm{NO}_{2}$ & Sphinganine & Serum $\uparrow \# \#$ & 4.5389 \\
\hline 34 & 7.45 & 159.0447 & $\mathrm{M}-\mathrm{H}$ & HMDB60497 & $\mathrm{C}_{10} \mathrm{H}_{8} \mathrm{O}_{2}$ & Naphthalene-1,2-diol & Urine & 4.6030 \\
\hline 35 & 7.56 & 319.2280 & $\mathrm{M}-\mathrm{H}$ & HMDB60102 & $\mathrm{C}_{20} \mathrm{H}_{32} \mathrm{O}_{3}$ & Arachidonate & Lung $\uparrow \# \#$ & 3.7587 \\
\hline 36 & 7.74 & 303.0830 & $\mathrm{M}-\mathrm{H}$ & HMDB01067 & $\mathrm{C}_{11} \mathrm{H}_{16} \mathrm{~N}_{2} \mathrm{O}_{8}$ & N-Acetylaspartylglutamic acid & Urine $\downarrow \# \#$ & 2.2912 \\
\hline 37 & 7.97 & 522.3542 & $\mathrm{M}+\mathrm{H}$ & HMDB02815 & $\mathrm{C}_{26} \mathrm{H}_{52} \mathrm{NO}_{7} \mathrm{P}$ & LysoPC(18:1(9Z)) & Lung个\#\# & 1.8640 \\
\hline 38 & 8.11 & 303.2314 & $\mathrm{M}+\mathrm{H}, 2 \mathrm{M}+\mathrm{H}$ & HMDB01999 & $\mathrm{C}_{20} \mathrm{H}_{30} \mathrm{O}_{2}$ & Eicosapentaenoic acid & Lung $\uparrow \# \#$ & 2.2904 \\
\hline 39 & 8.35 & 417.1798 & $\mathrm{M}+\mathrm{FA}-\mathrm{H}$ & HMDB03134 & $\mathrm{C}_{16} \mathrm{H}_{28} \mathrm{~N}_{4} \mathrm{O}_{4} \mathrm{~S}$ & Biocytin & Urine $\uparrow \# \#$ & 1.5952 \\
\hline 40 & 8.96 & 251.1994 & $\mathrm{M}+\mathrm{Na}$ & HMDB00806 & $\mathrm{C}_{14} \mathrm{H}_{28} \mathrm{O}_{2}$ & Myristic acid & Serum $\uparrow \#$ & 2.9917 \\
\hline 41 & 10.34 & 301.2175 & $\mathrm{M}-\mathrm{H}$ & HMDB01999 & $\mathrm{C}_{20} \mathrm{H}_{30} \mathrm{O}_{2}$ & Eicosapentaenoic acid & Serum $\uparrow \# \#$ & 2.6415 \\
\hline 42 & 11.46 & 357.0614 & $\mathrm{M}+\mathrm{FA}-\mathrm{H}$ & HMDB06552 & $\mathrm{C}_{17} \mathrm{H}_{12} \mathrm{O}_{6}$ & Aflatoxin B1 & Urine $\downarrow \# \#$ & 20.4369 \\
\hline 43 & 11.64 & 279.2309 & $\mathrm{M}+\mathrm{H}$ & HMDB01388 & $\mathrm{C}_{18} \mathrm{H}_{30} \mathrm{O}_{2}$ & Alpha-linolenic acid & Serum\\
#\# & 7.9317 \\
\hline 44 & 11.91 & 363.0159 & $\mathrm{M}-\mathrm{H}$ & HMDB60416 & $\mathrm{C}_{10} \mathrm{H}_{13} \mathrm{~N}_{4} \mathrm{O}_{7} \mathrm{PS}$ & 6-thioinosine-5'-monophosphate & Urine $\downarrow \# \#$ & 1.6801 \\
\hline 45 & 11.99 & 510.3905 & $\mathrm{M}+\mathrm{H}, \mathrm{M}+\mathrm{Na}$ & HMDB11149 & $\mathrm{C}_{26} \mathrm{H}_{56} \mathrm{NO}_{6} \mathrm{P}$ & LysoPC $(0-18: 0)$ & Lung $\uparrow \# \#$ & 1.8216 \\
\hline 46 & 13.43 & 327.2334 & $\mathrm{M}-\mathrm{H}$ & HMDB02183 & $\mathrm{C}_{22} \mathrm{H}_{32} \mathrm{O}_{2}$ & Docosahexaenoic acid & Lung $\uparrow \# \#$ & 3.7972 \\
\hline 47 & 13.90 & 305.2472 & $\mathrm{M}+\mathrm{H}$ & HMDB01043 & $\mathrm{C}_{20} \mathrm{H}_{32} \mathrm{O}_{2}$ & Arachidonic acid & Lung $\uparrow \#$ & 1.4143 \\
\hline 48 & 14.47 & 383.3293 & $\mathrm{M}+\mathrm{H}$ & HMDB03896 & $\mathrm{C}_{27} \mathrm{H}_{42} \mathrm{O}$ & 7-dehydrodesmosterol & Serum\\
# & 5.8721 \\
\hline 49 & 15.06 & 327.2337 & $\mathrm{M}-\mathrm{H}$ & HMDB02183 & $\mathrm{C}_{22} \mathrm{H}_{32} \mathrm{O}_{2}$ & Docosahexaenoic acid & Serum†\#\# & 2.0005 \\
\hline 50 & 15.20 & 573.2078 & $\mathrm{M}-\mathrm{H}$ & HMDB06825 & $\mathrm{C}_{24} \mathrm{H}_{30} \mathrm{~N}_{8} \mathrm{O}_{9}$ & Tetrahydrofolyl-[Glu](2) & Urine & 3.7036 \\
\hline 51 & 15.28 & 385.3445 & $\mathrm{M}+\mathrm{H}$ & HMDB02719 & $\mathrm{C}_{27} \mathrm{H}_{44} \mathrm{O}$ & Desmosterol & Serum\\
#\# & 5.7013 \\
\hline 52 & 15.48 & 319.2282 & $\mathrm{M}-\mathrm{H}$ & HMDB60102 & $\mathrm{C}_{20} \mathrm{H}_{32} \mathrm{O}_{3}$ & Arachidonate & Serum $\uparrow \# \#$ & 1.9411 \\
\hline 53 & 15.48 & 303.2339 & $\mathrm{M}-\mathrm{H}$ & HMDB01043 & $\mathrm{C}_{20} \mathrm{H}_{32} \mathrm{O}_{2}$ & Arachidonic acid & Serum $\uparrow \# \#$ & 3.1049 \\
\hline 54 & 15.78 & 734.5678 & $\mathrm{M}+\mathrm{H}$ & HMDB00564 & $\mathrm{C}_{40} \mathrm{H}_{80} \mathrm{NO}_{8} \mathrm{P}$ & $\mathrm{PC}(16: 0 / 16: 0)$ & Lung $\uparrow \# \#$ & 4.0799 \\
\hline 55 & 17.36 & 281.2495 & $\mathrm{M}-\mathrm{H}$ & HMDB00207 & $\mathrm{C}_{18} \mathrm{H}_{34} \mathrm{O}_{2}$ & Oleic acid & Serum个\#\# & 4.5778 \\
\hline 56 & 17.85 & 302.3044 & $\mathrm{M}+\mathrm{H}$ & HMDB00269 & $\mathrm{C}_{18} \mathrm{H}_{39} \mathrm{NO}_{2}$ & Sphinganine & Urine $\uparrow \# \#$ & 3.2284 \\
\hline
\end{tabular}

Compared with the MPP group, $\uparrow$ means increase, $\downarrow$ means decrease, \#p $<0.05$, \#\#p $<0.01$.

core targets to form a core target network2. After deleting the isolated nodes and connected edges, there are six nodes and 13 edges in the network (Figure 8C). Extract six core targets and their directly connected nodes to form a core target network 3 , which has 56 nodes and 341 edges (Figure 8D). There are only six core targets, but they are connected to $83.58 \%$ of the nodes (56/ 

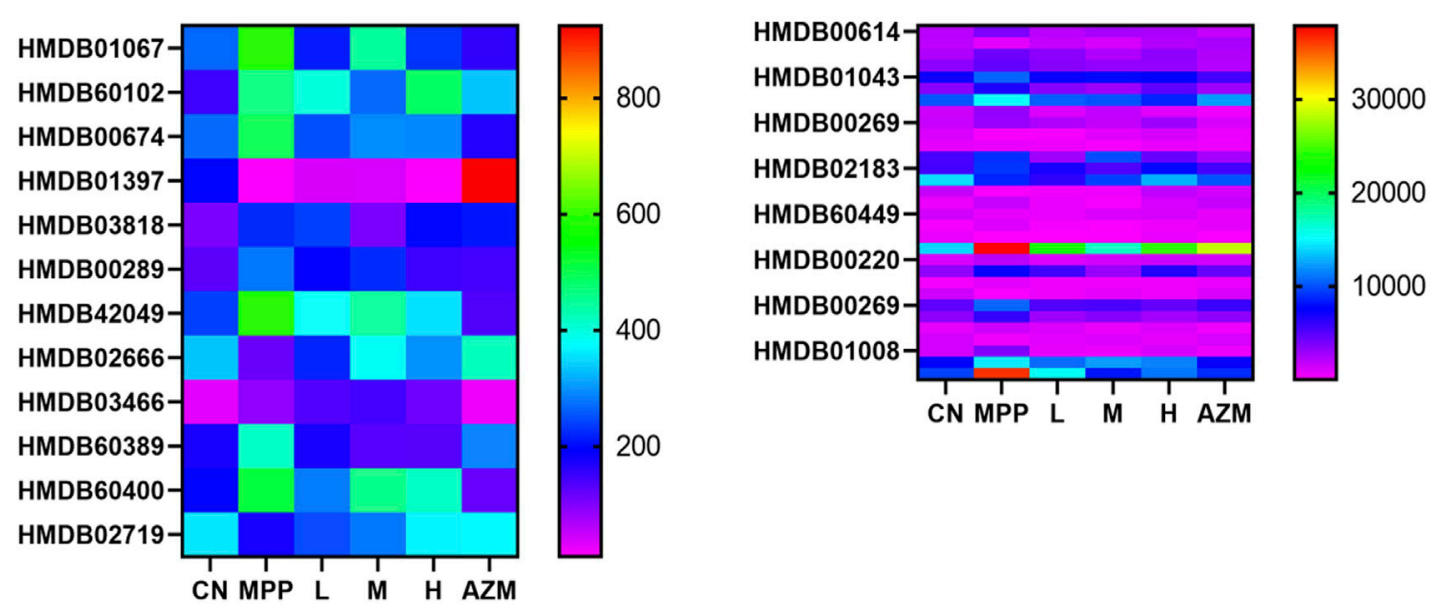

FIGURE 5 | Urine, serum, and lung tissue have a tendency to recall the biomarker.

67) and $88.80 \%$ of the edges $(341 / 384)$ of the T-D network. It shows that these six nodes play an extremely important role in maintaining the stability of the T-D network.

\section{Molecular Docking Verification}

The four core components luteolin, guanosine, wogonin, and isorhamnetin and the six core targets SIRT1, IL-10, MMP9, CTNNB1, CRP, and EGFR were screened for molecular docking according to their binding affinity. It is generally believed that the absolute value of the connection affinity energy value is close to or greater than the original protein docking energy value, which means that the docking is completed. In this experiment, good results were obtained except for CRP and the protein configuration of IL-10 was not found in the database, considering that it plays a significant role as a signal factor involved in inhibiting inflammation, promoting humoral immunity, and tissue repair (Hendriks et al., 2004; Zhang et al., 2019; Singh et al., 2020). Finally, as shown in Figure 8, it demonstrated good binding ability (Figure 9A). The docking effect between the core target and the core component is shown in Figure 9B.

\section{Gene and Biomarker Enrichment Analysis}

The selected core biomarkers and core target enrichment analysis are integrated with pathway over-representation analysis. The biologically significant pathways satisfying $p<0.05$ and $\mathrm{Q}<0.05$ are shown in the following table (Table 4). Through the combined analysis of metabolomics and network pharmacology, it can be seen that QB mainly interfere with the $G$ alpha (q) signaling events, GPCR downstream signaling, signal transduction, signaling by GPCR, spinal cord injury, GnRH signaling pathway, relationship between inflammation COX-2 and EGFR, and other interventions in the disease process, mainly the intervention of G-protein-coupled receptors, and EGFR. Through the analysis of the combined path of the two, G-protein-coupled receptors can directly promote the activation of the PI3K pathway (Li et al., 2021), while EGFR directly promotes the expression of Twist2 (Lehman et al., 2020). Both the STAT3 and PI3K pathways act as the direct upstream of the NF- $\kappa \mathrm{B}$ pathway, directly or through Twist2, promoting the activation of the NF- $\kappa B$ pathway (Figure 10).

\section{Western Blotting Detection}

Through the analysis of the combined path of biomarkers and core disease targets, it is further obtained that its main function and the intracellular NF- $\kappa B$ pathway are found through further analysis, and TLR-MyD88-NF- $\kappa B$ p65 is the most critical signaling pathway for the pathogenesis and treatment of MPP. The TLR4/MyD88/NF- $\kappa \mathrm{B}$ signaling pathway is involved in the body's immune response and alveolar inflammation. TLR4 is activated after body injury, which further promotes the expression of downstream factors MyD88 and NF- $\mathrm{KB}$ and promotes the expression of inflammatory factors. This causes the alveolar epithelial cells to synthesize and secrete pulmonary inflammation-related cytokines and alveolar epithelial cell apoptosis, leading to the occurrence of pneumonia (Wang et al., 2020).

The protein expression detection was carried out according to the Western Blot method. The results are shown in Figure 11A. Compared with the blank group, the protein band of the model group was deepened and there was a trend of callback after administration. The callback trend of $\mathrm{M}$ and $\mathrm{H}$ is similar or better than that of the $\mathrm{CN}$.

Using the gray value to analyze the protein expression level, the high dose has a better callback effect on NF- $\kappa$ B p65 than azithromycin $(p<0.05)$. The regulation of the upstream protein shows an obvious trend of superiority with increasing dose. The middle dose inhibited MyD88 the strongest. This reflects that a high dose has the advantage of strongly inhibiting the NF- $\kappa \mathrm{B}$ pathway, but does not directly inhibit the agonistic ability of toll-like receptors. It may even have a certain activation ability. In this case, the middle dose is considered the optimal dose (Figure 11B). 
TABLE 2 | Composition of QB into the blood and lung tissue.

\begin{tabular}{|c|c|c|c|c|c|c|c|c|}
\hline No & Rt(s) & $\begin{array}{l}\text { Common } \\
\text { name }\end{array}$ & $\begin{array}{l}\text { Chemical } \\
\text { formula }\end{array}$ & $\mathbf{M} \pm \mathbf{H}$ & $\begin{array}{l}\text { Predicted } \\
\text { value }\end{array}$ & $\begin{array}{l}\text { Actual } \\
\text { value }\end{array}$ & $\begin{array}{l}\text { Error } \\
\text { (ppm) }\end{array}$ & $\begin{array}{l}\text { Fragment } \\
\text { ion }\end{array}$ \\
\hline 1 & 1.75 & Malic acid & $\mathrm{C}_{4} \mathrm{H}_{6} \mathrm{O}_{5}$ & $\mathrm{M}+\mathrm{Na}$ & 157.01074 & 157.01211 & 8.7 & $157[\mathrm{M}+\mathrm{Na}]^{+}, 139\left[\mathrm{M}+\mathrm{Na}-\mathrm{H}_{2} \mathrm{O}\right]^{+}, 111\left[\mathrm{M}-\mathrm{H}_{2} \mathrm{O}-\mathrm{CO}\right]^{+}$ \\
\hline 2 & 1.86 & Casticin & $\mathrm{C}_{19} \mathrm{H}_{18} \mathrm{O}_{8}$ & $\mathrm{M}+\mathrm{H}$ & 375.10744 & 375.10801 & 1.5 & $\begin{array}{l}375[\mathrm{M}+\mathrm{H}]^{+}, 243\left[\mathrm{M}+\mathrm{H}-\mathrm{C}_{8} \mathrm{H}_{4} \mathrm{O}_{2}\right]^{+}, 110 \\
{\left[\mathrm{M}+\mathrm{H}-\mathrm{CH}_{3}-\mathrm{C}_{12} \mathrm{H}_{10} \mathrm{O}_{6}\right]^{+}}\end{array}$ \\
\hline 3 & 1.87 & Astin B & $\mathrm{C}_{25} \mathrm{H}_{33} \mathrm{~N}_{5} \mathrm{O}_{7} \mathrm{Cl}_{2}$ & $\mathrm{M}+\mathrm{Na}$ & 608.16493 & 608.16795 & 5.0 & $608[\mathrm{M}+\mathrm{Na}]^{+}, 231\left[\mathrm{M}+\mathrm{Na}-\mathrm{C}_{14} \mathrm{H}_{16} \mathrm{~N}_{3} \mathrm{O}_{5} \mathrm{Cl}_{2}\right]^{+}$ \\
\hline 4 & 1.98 & Eriodictyol & $\mathrm{C}_{15} \mathrm{H}_{12} \mathrm{O}_{6}$ & $\mathrm{M}+\mathrm{H}$ & 289.07066 & 289.07032 & -1.2 & $289[\mathrm{M}+\mathrm{H}]^{+}, 271\left[\mathrm{M}+\mathrm{H}-\mathrm{H}_{2} \mathrm{O}\right]^{+}, 217\left[\mathrm{M}+\mathrm{H}-4 \mathrm{H}_{2} \mathrm{O}\right]^{+}$ \\
\hline 5 & 2.52 & Tuberospironine & $\mathrm{C}_{18} \mathrm{H}_{27} \mathrm{NO}_{5}$ & $\mathrm{M}+\mathrm{H}$ & 338.19620 & 338.19617 & -0.1 & $\begin{array}{l}338[\mathrm{M}+\mathrm{H}]^{+}, 32 \mathrm{O}\left[\mathrm{M}+\mathrm{H}-\mathrm{H}_{2} \mathrm{O}\right]^{+}, 292\left[\mathrm{M}+\mathrm{H}-\mathrm{H}_{2} \mathrm{O}-\mathrm{CO}\right]^{+}, 264 \\
{\left[\mathrm{M}+\mathrm{H}-\mathrm{C}_{3} \mathrm{H}_{6} \mathrm{O}_{2}\right]^{+}, 252\left[\mathrm{M}+\mathrm{H}-\mathrm{C}_{4} \mathrm{H}_{6} \mathrm{O}_{2}\right]^{+}, 236} \\
{\left[\mathrm{M}+\mathrm{H}-\mathrm{C}_{4} \mathrm{H}_{6} \mathrm{O}_{3}\right]^{+}}\end{array}$ \\
\hline 6 & 2.66 & Stemotinine & $\mathrm{C}_{18} \mathrm{H}_{25} \mathrm{NO}_{5}$ & $\mathrm{M}+\mathrm{H}$ & 336.18055 & 336.18075 & 0.6 & $\begin{array}{l}336[\mathrm{M}+\mathrm{H}]^{+}, 308[\mathrm{M}+\mathrm{H}-\mathrm{CO}]^{+}, 238\left[\mathrm{M}+\mathrm{H}-\mathrm{CO}-\mathrm{C}_{4} \mathrm{H}_{7} \mathrm{O}\right]^{+}, 222 \\
{\left[\mathrm{M}+\mathrm{H}-\mathrm{C}_{5} \mathrm{H}_{7} \mathrm{O}_{2}-\mathrm{O}\right]^{+}, 152\left[\mathrm{M}+\mathrm{H}-\mathrm{C}_{5} \mathrm{H}_{7} \mathrm{O}_{2}-\mathrm{C}_{4} \mathrm{H}_{6} \mathrm{O}_{2}\right]^{+}}\end{array}$ \\
\hline 7 & 2.79 & Tuberostemoline & $\mathrm{C}_{22} \mathrm{H}_{31} \mathrm{NO}_{7}$ & $\mathrm{M}+\mathrm{H}$ & 422.21733 & 422.21698 & -0.8 & $422[\mathrm{M}+\mathrm{H}]^{+}, 376\left[\mathrm{M}+\mathrm{H}-\mathrm{CH}_{2} \mathrm{O}_{2}\right]^{+}, 336\left[\mathrm{M}+\mathrm{H}-\mathrm{C}_{4} \mathrm{H}_{6} \mathrm{O}_{2}\right]^{+}$ \\
\hline 8 & 2.87 & Trans-Caffeic acid & $\mathrm{C}_{9} \mathrm{H}_{8} \mathrm{O}_{4}$ & $\mathrm{M}+\mathrm{H}$ & 181.04954 & 181.04926 & -1.5 & $181[\mathrm{M}+\mathrm{H}]^{+}, 152[\mathrm{M}+\mathrm{H}-\mathrm{CHO}]^{+}$ \\
\hline 9 & 3.13 & Croomine & $\mathrm{C}_{18} \mathrm{H}_{27} \mathrm{NO}_{4}$ & $\mathrm{M}+\mathrm{H}$ & 322.20129 & 322.20199 & 2.2 & $\begin{array}{l}322[\mathrm{M}+\mathrm{H}]^{+}, 248\left[\mathrm{M}+\mathrm{H}-\mathrm{C}_{3} \mathrm{H}_{6} \mathrm{O}_{2}\right]^{+}, 162 \\
{\left[\mathrm{M}+\mathrm{H}-2 \mathrm{C}_{3} \mathrm{H}_{6} \mathrm{O}_{2}\right]^{+}, 136\left[\mathrm{M}+\mathrm{H}-2 \mathrm{C}_{3} \mathrm{H}_{6} \mathrm{O}_{2}-\mathrm{C}_{2} \mathrm{H}_{4}\right]^{+}}\end{array}$ \\
\hline 10 & 3.20 & Chlorogenic acid & $\mathrm{C}_{10} \mathrm{H}_{10} \mathrm{O}_{4}$ & $\mathrm{M}-\mathrm{H}$ & 193.05063 & 193.05080 & 0.9 & $193[\mathrm{M}-\mathrm{H}]^{-}, 149[\mathrm{M}-\mathrm{H}-\mathrm{H} 2 \mathrm{O}-\mathrm{CO}]^{-}, 121\left[\mathrm{M}-\mathrm{H}-\mathrm{H}_{2} \mathrm{O}-2 \mathrm{CO}\right]^{-}$ \\
\hline 11 & 3.24 & Asterin A & $\mathrm{C}_{25} \mathrm{H}_{33} \mathrm{~N}_{5} \mathrm{O}_{8}$ & $\mathrm{M}-\mathrm{H}$ & 530.22564 & 530.22387 & -3.3 & $530[\mathrm{M}-\mathrm{H}]^{-}, 486\left[\mathrm{M}-\mathrm{H}-\mathrm{CH}_{2} \mathrm{NO}\right]^{-}, 251\left[\mathrm{M}-\mathrm{H}-\mathrm{C}_{14} \mathrm{H}_{15} \mathrm{O}_{6}\right]^{-}$ \\
\hline 12 & 3.45 & Sessillistemonamine A & $\mathrm{C}_{22} \mathrm{H}_{33} \mathrm{NO}_{5}$ & $\mathrm{M}+\mathrm{H}$ & 392.24315 & 392.24299 & -0.4 & $392[\mathrm{M}+\mathrm{H}]^{+}, 318\left[\mathrm{M}+\mathrm{H}-\mathrm{C}_{4} \mathrm{H}_{10} \mathrm{O}\right]^{+}$ \\
\hline 13 & 3.51 & Mirificin & $\mathrm{C}_{26} \mathrm{H}_{28} \mathrm{O}_{13}$ & $\mathrm{M}-\mathrm{H}$ & 547.14571 & 547.14649 & 1.4 & $\begin{array}{l}547[\mathrm{M}-\mathrm{H}]^{-}, 457\left[\mathrm{M}-\mathrm{H}-5 \mathrm{H}_{2} \mathrm{O}\right]^{-}, 367\left[\mathrm{M}-\mathrm{H}-\mathrm{C}_{6} \mathrm{H}_{12} \mathrm{O}_{6}\right]^{-}, 337 \\
{\left[\mathrm{M}-\mathrm{H}-\mathrm{C}_{6} \mathrm{H}_{12} \mathrm{O}_{6}-\mathrm{CH}_{2} \mathrm{O}\right]^{-}}\end{array}$ \\
\hline 14 & 3.51 & Astin $J$ & $\mathrm{C}_{25} \mathrm{H}_{33} \mathrm{O}_{7} \mathrm{~N}_{5}$ & $\mathrm{M}-\mathrm{H}$ & 514.23072 & 514.22924 & -2.9 & $514[\mathrm{M}-\mathrm{H}]^{-}, 484\left[\mathrm{M}-\mathrm{H}-2 \mathrm{CH}_{3}\right]^{-}, 251\left[\mathrm{M}-\mathrm{H}-\mathrm{C}_{12} \mathrm{H}_{13} \mathrm{~N}_{3} \mathrm{O}_{4}\right]^{-}$ \\
\hline 15 & 3.68 & Isorhamnetin & $\mathrm{C}_{16} \mathrm{H}_{12} \mathrm{O}_{7}$ & $\mathrm{M}+\mathrm{H}$ & 317.06558 & 317.06503 & -1.7 & $317[\mathrm{M}+\mathrm{H}]^{+}, 136\left[\mathrm{M}+\mathrm{H}-\mathrm{C}_{9} \mathrm{H}_{9} \mathrm{O}_{4}\right]^{+}, 111\left[\mathrm{M}+\mathrm{H}-\mathrm{C}_{10} \mathrm{H}_{6} \mathrm{O}_{5}\right]^{+}$ \\
\hline 16 & 3.69 & Wogonin & $\mathrm{C}_{16} \mathrm{H}_{12} \mathrm{O}_{5}$ & $\mathrm{M}+\mathrm{H}$ & 285.07575 & 285.07575 & 0 & $\begin{array}{l}285[\mathrm{M}+\mathrm{H}]^{+}, 27 \mathrm{O}\left[\mathrm{M}+\mathrm{H}-\mathrm{CH}_{3}\right]^{+}, 253\left[\mathrm{M}+\mathrm{H}-\mathrm{CH}_{4} \mathrm{O}\right]^{+}, 225 \\
{\left[\mathrm{M}+\mathrm{H}-\mathrm{C}_{2} \mathrm{H}_{4} \mathrm{O}_{2}\right]^{+}, 213\left[\mathrm{M}+\mathrm{H}-\mathrm{C}_{3} \mathrm{H}_{4} \mathrm{O}_{2}\right]^{+}, 197} \\
{\left[\mathrm{M}+\mathrm{H}-\mathrm{C}_{3} \mathrm{H}_{4} \mathrm{O}_{3}\right]^{+}, 137\left[\mathrm{M}+\mathrm{H}-\mathrm{C}_{3} \mathrm{H}_{4} \mathrm{O}_{2}-\mathrm{C}_{6} \mathrm{H}_{4}\right]^{+}}\end{array}$ \\
\hline 17 & 3.72 & Wogonoside & $\mathrm{C}_{22} \mathrm{H}_{20} \mathrm{O}_{11}$ & $\mathrm{M}+\mathrm{H}$ & 461.10784 & 461.10800 & 0.3 & $461[\mathrm{M}+\mathrm{H}]^{+}, 285\left[\mathrm{M}+\mathrm{H}-\mathrm{C}_{6} \mathrm{H}_{8} \mathrm{O}_{6}\right]^{+}, 270\left[\mathrm{M}+\mathrm{H}-\mathrm{C}_{6} \mathrm{H}_{8} \mathrm{O}_{6}-\mathrm{CH}_{3}\right]^{+}$ \\
\hline 18 & 3.76 & Oxystemoninine & $\mathrm{C}_{22} \mathrm{H}_{33} \mathrm{NO}_{6}$ & $\mathrm{M}+\mathrm{H}$ & 408.23806 & 408.23762 & -1.1 & $408[\mathrm{M}+\mathrm{H}]^{+}, 362\left[\mathrm{M}+\mathrm{H}-\mathrm{CH}_{2} \mathrm{O}_{2}\right]^{+}, 322\left[\mathrm{M}+\mathrm{H}-\mathrm{C}_{4} \mathrm{H}_{6} \mathrm{O}_{2}\right]^{+}$ \\
\hline 19 & 3.80 & Scutellarin & $\mathrm{C}_{21} \mathrm{H}_{18} \mathrm{O}_{12}$ & $\mathrm{M}-\mathrm{H}$ & 461.07255 & 461.07244 & -0.2 & $461[\mathrm{M}-\mathrm{H}]^{-}, 285\left[\mathrm{M}-\mathrm{H}-\mathrm{C}_{6} \mathrm{H}_{8} \mathrm{O}_{6}\right]^{-}$ \\
\hline 20 & 3.80 & Tuberostemoninol A & $\mathrm{C}_{22} \mathrm{H}_{31} \mathrm{NO}_{6}$ & $\mathrm{M}+\mathrm{H}$ & 406.22241 & 406.22281 & 1.0 & $\begin{array}{l}406[\mathrm{M}+\mathrm{H}]^{+}, 388\left[\mathrm{M}+\mathrm{H}-\mathrm{H}_{2} \mathrm{O}\right]^{+}, 360\left[\mathrm{M}+\mathrm{H}-\mathrm{H}_{2} \mathrm{O}-\mathrm{CO}\right]^{+}, 200 \\
{\left[\mathrm{M}+\mathrm{H}-\mathrm{C}_{11} \mathrm{H}_{12} \mathrm{NO}_{3}\right]^{+}, 182\left[\mathrm{M}+\mathrm{H}-\mathrm{C}_{11} \mathrm{H}_{12} \mathrm{NO}_{3}-\mathrm{H}_{2} \mathrm{O}\right]^{+}}\end{array}$ \\
\hline 21 & 3.94 & Tuberostemonine & $\mathrm{C}_{22} \mathrm{H}_{33} \mathrm{NO}_{4}$ & $\mathrm{M}+\mathrm{H}$ & 376.24824 & 376.24807 & -0.5 & $376[\mathrm{M}+\mathrm{H}]^{+}, 302\left[\mathrm{M}+\mathrm{H}-\mathrm{C}_{3} \mathrm{H}_{6} \mathrm{O}_{2}\right]^{+}$ \\
\hline 22 & 4.00 & Stemoninine $A / B$ & $\mathrm{C}_{22} \mathrm{H}_{29} \mathrm{NO}_{5}$ & $\mathrm{M}+\mathrm{H}$ & 388.21185 & 388.21174 & -0.3 & $\begin{array}{l}388[\mathrm{M}+\mathrm{H}]^{+}, 221\left[\mathrm{M}+\mathrm{H}-\mathrm{C}_{9} \mathrm{H}_{13} \mathrm{NO}_{2}\right]^{+}, 182 \\
{\left[\mathrm{M}+\mathrm{H}-\mathrm{C}_{9} \mathrm{H}_{13} \mathrm{NO}_{2}-\mathrm{C}_{3} \mathrm{H}_{3}\right]^{+}}\end{array}$ \\
\hline 23 & 4.15 & Baicalcin & $\mathrm{C}_{15} \mathrm{H}_{10} \mathrm{O}_{5}$ & $\mathrm{M}-\mathrm{H}$ & 269.04555 & 269.04506 & -1.8 & $\begin{array}{l}269[\mathrm{M}-\mathrm{H}]^{-}, 213\left[\mathrm{M}-\mathrm{H}-\mathrm{H}_{2} \mathrm{O}-\mathrm{C}_{2} \mathrm{HO}\right]^{-}, 197 \\
{\left[\mathrm{M}+\mathrm{H}-2 \mathrm{H}_{2} \mathrm{O}-\mathrm{C}_{2} \mathrm{HO}\right]^{-}}\end{array}$ \\
\hline 24 & 4.76 & Skullcapflavone II & $\mathrm{C}_{19} \mathrm{H}_{18} \mathrm{O}_{8}$ & $\mathrm{M}+\mathrm{H}$ & 375.10744 & 375.10749 & 0.1 & $375[\mathrm{M}+\mathrm{H}]^{+}, 345\left[\mathrm{M}+\mathrm{H}-2 \mathrm{CH}_{3}\right]^{+}, 327\left[\mathrm{M}+\mathrm{H}-2 \mathrm{CH}_{3}-\mathrm{H}_{2} \mathrm{O}\right]^{+}$ \\
\hline 25 & 4.78 & Skullcapflavone I & $\mathrm{C}_{17} \mathrm{H}_{14} \mathrm{O}_{6}$ & $\mathrm{M}+\mathrm{H}$ & 315.08631 & 315.08661 & 0.9 & $\begin{array}{l}315[\mathrm{M}+\mathrm{H}]^{+}, 300\left[\mathrm{M}+\mathrm{H}-\mathrm{CH}_{3}\right]^{+}, 285\left[\mathrm{M}+\mathrm{H}-\mathrm{CH}_{2} \mathrm{O}\right]^{+}, 257 \\
{\left[\mathrm{M}+\mathrm{H}-\mathrm{CH}_{2} \mathrm{O}-\mathrm{CO}\right]^{+}, 182\left[\mathrm{M}+\mathrm{H}-\mathrm{CH}_{2} \mathrm{O}-\mathrm{C}_{7} \mathrm{H}_{3} \mathrm{O}\right]^{+}, 154} \\
{\left[\mathrm{M}+\mathrm{H}-\mathrm{C}_{8} \mathrm{H}_{5} \mathrm{O}_{2}-\mathrm{CO}\right]^{+}}\end{array}$ \\
\hline 26 & 4.81 & Tectorigenin & $\mathrm{C}_{16} \mathrm{H}_{12} \mathrm{O}_{6}$ & $\mathrm{M}+\mathrm{H}$ & 301.07066 & 301.07038 & -1.0 & $301[\mathrm{M}+\mathrm{H}]^{+}, 286\left[\mathrm{M}+\mathrm{H}-\mathrm{CH}_{3}\right]^{+}, 183\left[\mathrm{M}+\mathrm{H}-\mathrm{C}_{8} \mathrm{H}_{6} \mathrm{O}\right]^{+}$ \\
\hline 27 & 5.09 & Aurantio-obtusin & $\mathrm{C}_{17} \mathrm{H}_{14} \mathrm{O}_{7}$ & $\mathrm{M}+\mathrm{H}$ & 331.08123 & 331.07986 & -4.1 & $331[\mathrm{M}+\mathrm{H}]^{+}, 301\left[\mathrm{M}+\mathrm{H}-2 \mathrm{CH}_{3}\right]^{+}$ \\
\hline 28 & 5.24 & luteolin & $\mathrm{C}_{15} \mathrm{H}_{10} \mathrm{O}_{6}$ & $\mathrm{M}-\mathrm{H}$ & 285.04046 & 285.04019 & -1.0 & $\begin{array}{l}285[\mathrm{M}-\mathrm{H}]^{-}, 151\left[\mathrm{M}-\mathrm{H}-\mathrm{C}_{8} \mathrm{H}_{6} \mathrm{O}_{2}\right]^{-}, 133 \\
{\left[\mathrm{M}-\mathrm{H}-\mathrm{C}_{8} \mathrm{H}_{6} \mathrm{O}_{2}-\mathrm{H}_{2} \mathrm{O}\right]^{-}, 125\left[\mathrm{M}-\mathrm{H}-\mathrm{C}_{9} \mathrm{H}_{4} \mathrm{O}_{3}\right]^{-}}\end{array}$ \\
\hline 29 & 5.63 & Riboderm & $\mathrm{C}_{17} \mathrm{H}_{20} \mathrm{~N}_{4} \mathrm{O}_{6}$ & $\mathrm{M}+\mathrm{Na}$ & 399.12751 & 399.12951 & 5.0 & $\begin{array}{l}399[\mathrm{M}+\mathrm{Na}]^{+}, 319\left[\mathrm{M}-3 \mathrm{H}_{2} \mathrm{O}-\mathrm{CO}\right]^{+}, 212 \\
{\left[\mathrm{M}+\mathrm{H}-\mathrm{C}_{7} \mathrm{H}_{9} \mathrm{NO}_{5}\right]^{+}, 184\left[\mathrm{M}+\mathrm{H}-\mathrm{C}_{7} \mathrm{H}_{9} \mathrm{NO}_{5}-\mathrm{CO}\right]^{+}}\end{array}$ \\
\hline 30 & 6.12 & Guanosine & $\mathrm{C}_{10} \mathrm{H}_{13} \mathrm{~N}_{5} \mathrm{O}_{5}$ & $\mathrm{M}+\mathrm{Na}$ & 306.08089 & 306.08132 & 1.4 & $306[\mathrm{M}+\mathrm{Na}]^{+}, 246\left[\mathrm{M}-\mathrm{C}_{2} \mathrm{H}_{4} \mathrm{O}_{2}\right]^{+}, 204\left[\mathrm{M}-\mathrm{C}_{2} \mathrm{H}_{4} \mathrm{O}_{2}-\mathrm{C}_{2} \mathrm{H}_{2} \mathrm{O}\right]^{+}$ \\
\hline 31 & 7.23 & Didehydrotuberostemoninee & $\mathrm{C}_{22} \mathrm{H}_{29} \mathrm{NO}_{4}$ & $\mathrm{M}+\mathrm{H}$ & 372.21694 & 372.21669 & -0.7 & $372[\mathrm{M}+\mathrm{H}]^{+}, 326\left[\mathrm{M}+\mathrm{H}-\mathrm{CH}_{2} \mathrm{O}_{2}\right]^{+}, 308\left[\mathrm{M}+\mathrm{H}-\mathrm{CH}_{2} \mathrm{O}_{2}-\mathrm{H}_{2} \mathrm{O}\right]^{+}$ \\
\hline
\end{tabular}

\section{CONCLUSION}

Firstly, we verified that QB has a good ability to treat mycoplasma pneumonia through pharmacodynamic evaluation. Then, we identified the main biomarkers of its action. Through the study of the rise and fall trends of these biomarkers, it can be proved that MPP causes the abnormal changes of the original biological small molecules in internal medicine. QB can regulate some substances, proving its ability to treat MPP. Subsequently, through extreme drug delivery, the compounds that can be directly absorbed and utilized are characterized, and the main action components and main disease treatment targets are identified through network pharmacology technology. The final disease treatment is determined through the verification of the molecular docking between the components and the target. The drug first acts on the target and regulates the body through the signal transduction pathway in the body. The final reflection is the changes in proteins and endogenous small molecules. In MPP, it is the recovery of inflammatory factor levels and biomarker levels. Finally, through the enrichment of quality markers and targets, the pathway was further comprehensively analyzed. It is also confirmed that MyD88/NF- $\mathrm{kB}$ is the main signal pathway for QB intervention and treatment of MPP. The verification and confirmation of the protein expression of QB-related pathways in the lung tissue can significantly inhibit the activation of this pathway, thereby regulating downstream signal factors. 


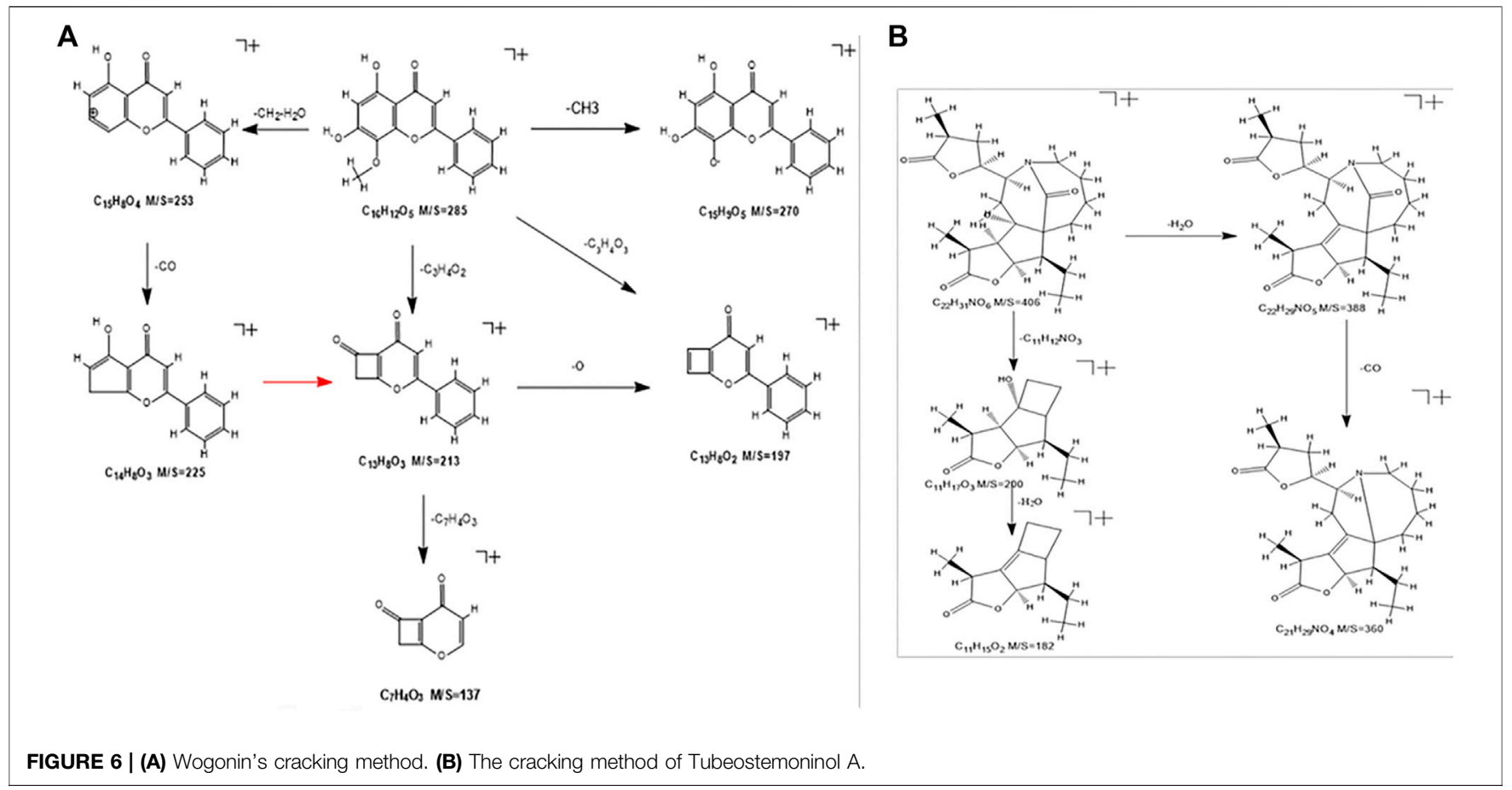

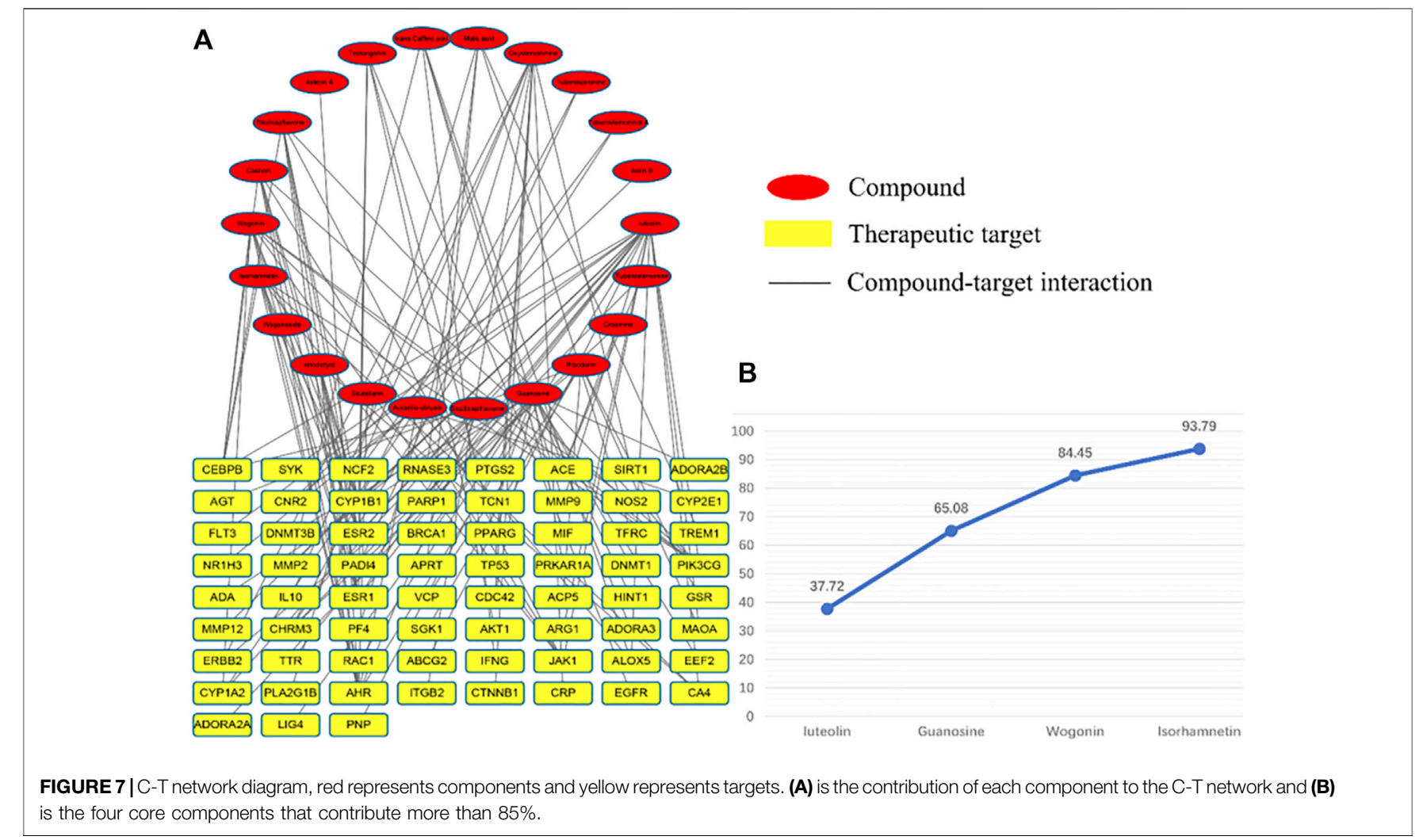

Both QB and AZM inhibited the survival of Mycoplasma in the lungs, restored normal immune levels, and repaired the damaged lungs. Compared with AZM, QB not only has a good ability to inhibit mycoplasma in the body but also has a better repair ability for inflammation infiltration. For long-lasting diseases caused by inflammatory damage, QB can inhibit pathogens while exerting a 
TABLE 3 | Core targets and correlation coefficients.

\begin{tabular}{|c|c|c|c|c|c|}
\hline name & AverageShortestPathLength & Betweenness & Closeness & Degree & Coreness \\
\hline SIRT1 & 1.65151515 & 0.09071521 & 0.60550459 & 24 & 9 \\
\hline IL-10 & 1.53030303 & 0.09502362 & 0.65346535 & 33 & 9 \\
\hline MMP9 & 1.60606061 & 0.07128803 & 0.62264151 & 28 & 9 \\
\hline CTNNB1 & 1.68181818 & 0.03984413 & 0.59459459 & 23 & 9 \\
\hline CRP & 1.68181818 & 0.04837266 & 0.59459459 & 22 & 8 \\
\hline EGFR & 1.57575758 & 0.04708932 & 0.63461538 & 29 & 8 \\
\hline
\end{tabular}

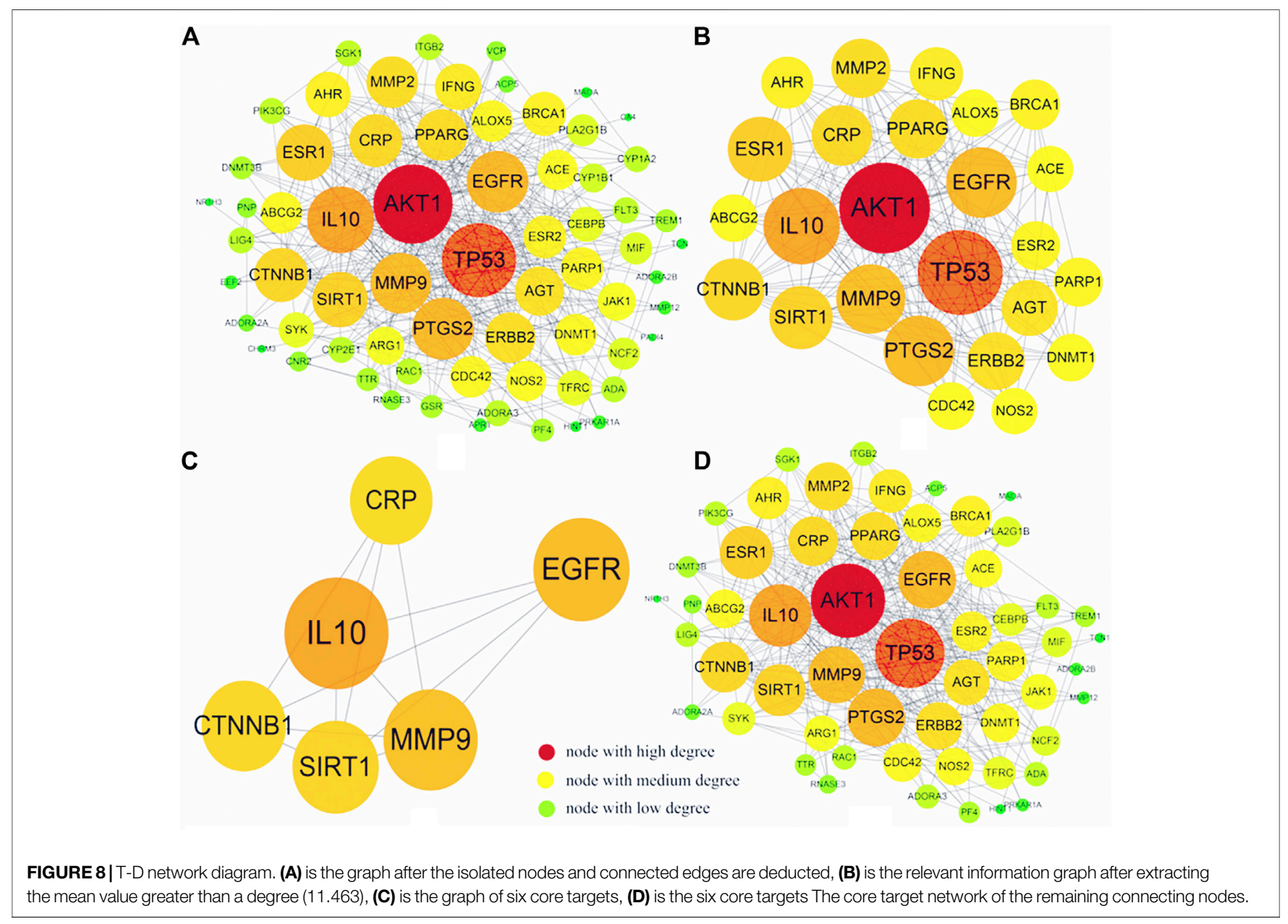

certain ability to promote body healing. Using the tracheal intubation technology to create the MPP model, the rat immune system has unusually strong resistance. The objectively evaluated physiological and biochemical indicators have evidence that both AZM and QB have shown strong strength in fighting pathogens. One question that needs to be considered is whether it is necessary to directly kill the pathogen while facing the invasion of some pathogens and whether some auxiliary means are needed to prevent the worsening of the disease. The prognosis is even more important. Preventing the persistent and repetitive development of inflammation is the key. We need to provide safe and reliable drugs to protect life and health, which requires us to evaluate drugs objectively and accurately. The application of safe and effective natural medicine adjuvant treatment is also key means to avoid antibiotic resistance.

The invasion of MP activates the body's innate immune system and the toll-like receptor 2 (TLR2) on immune cells that specifically bind to Mycoplasma pneumoniae. Then, inflammatory infiltration occurs, which stimulates the secretion of pro-inflammatory cytokines, interleukins, and chemokines (Cronin et al., 2012). Since the mucosa is the first barrier to pathogen infection, research on the signal cascade and subsequent expression of inflammatory mediators is the 

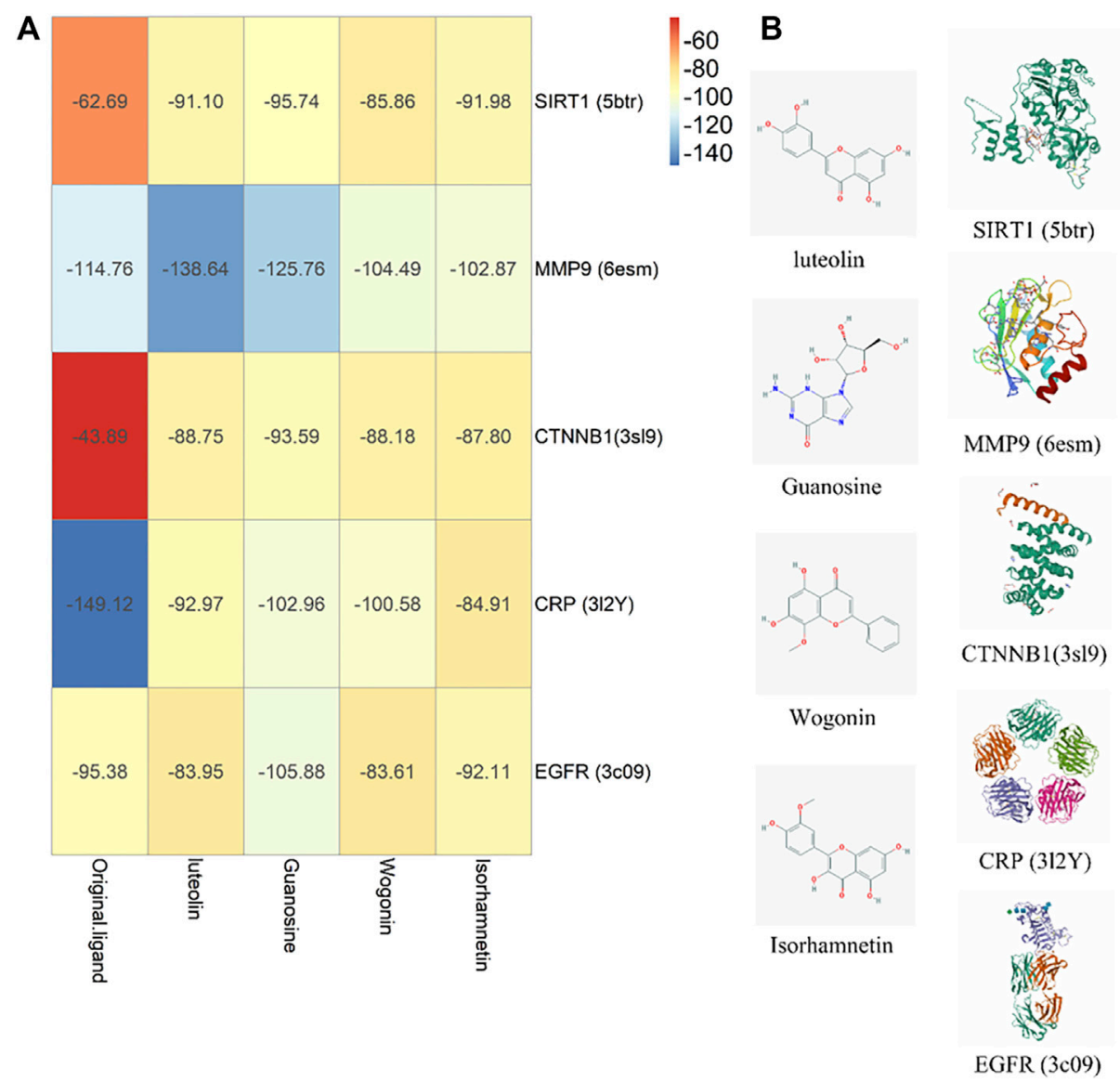

FIGURE 9 | Molecule docking verification diagram. (A) Component-target affinity energy heat map, the greater the absolute value of $\mathrm{kJ} / \mathrm{mol}$, the stronger the binding energy. (B) Molecule docking diagram.

key to studying the occurrence and development of diseases and drug treatment. The detection of pathogens in mammals depends on the recognition of pathogen-associated molecular patterns (PAMP) through pattern recognition receptors on cells of the innate immune system. The main family of pattern recognition receptors is ten toll-like receptors (TLR1-10) (Takeuchi and Akira, 2010). TLR2 and TLR4 specifically recognize MP and then through MyD88-dependent pathways. This leads to the recruitment, activation, and degradation of IRAK-1, degradation of the downstream protein I $\kappa B$ kinase (IKK) and NF- $\kappa B$ activation, which stimulates the NF- $\mathrm{B}$ activation expression of proinflammatory cytokines (IL-1 $\beta$, IL-6, IL-8, and TNF- $\alpha$ ) (Lye et al., 2004; Shimizu, 2016; Chen J. et al., 2020). NF$\kappa \mathrm{B}$ is a ubiquitous transcription factor with a wide range of target genes, mainly intervening in inflammation and immune processes. MPP causes the first activation of MyD88, and the recruitment of MyD88 is a prerequisite for inflammatory signal transduction and the convergence of a variety of pro-inflammatory cytokines. It is the unique target of severe pro-inflammatory cytokine signaling intervention (Saikh, 2021). The high expression of MyD88 also confirms the activation of TLRs (except TLR3). The inhibition of MyD88 homodimerization is a prerequisite for the inhibition of its downstream inflammatory pathway expression. After sending a signal to cause phosphorylation

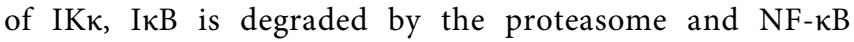
subunits p65 and p50 translocate to the nucleus (Chuffa et al., 2015). Therefore, it can be considered that MyD88 has the same trend with the entire NF- $\kappa B$ pathway. MPP caused an increase in the expression of MyD88 protein, reflecting the activation of the entire toll-like receptor. We noticed that AZM has a weak direct inhibitory ability on MyD88 while QBM $(0.16 \mathrm{~g} / \mathrm{ml})$ has a better effect on the entire signal pathway. Inhibition ability and downstream inflammatory factors also reflect this fact.

The biomarkers of metabolomics are mainly concentrated in lipid metabolism and amino acid metabolism. By promoting the expression of NF- $\kappa \mathrm{B}$, it accelerates the response to proinflammatory factors, including TNF- $\alpha$ release (Ding et al., 2021), while reducing the secretion of NO, iNOs, etc., (Lowry et al., 2020), reflecting the duality of lipid metabolism. The pro-inflammatory effect of lipid metabolism is reflected off the first invasion of pathogens. Molecules including arachidonic 
TABLE 4 | Enrichment analysis chart.

\begin{tabular}{|c|c|c|c|c|c|c|}
\hline Pathway & $\begin{array}{l}\text { Overlapping } \\
\text { genes }\end{array}$ & $\begin{array}{l}\text { Num all } \\
\text { pathway } \\
\text { genes }\end{array}$ & $\begin{array}{l}\text { Overlapping } \\
\text { metabolites }\end{array}$ & $\begin{array}{c}\text { Num all } \\
\text { pathway } \\
\text { metabolites }\end{array}$ & P Joint & Q joint \\
\hline G-alpha (q) signaling events & EGFR & $221(221)$ & $\begin{array}{l}\text { HMDB00181; HMDB00220; HMDB00674; } \\
\text { HMDB01388; HMDB00806; HMDB60102; } \\
\text { HMDB01043; HMDB00207; HMDB01999; } \\
\text { HMDB02183 }\end{array}$ & $56(64)$ & 2.99E-07 & $7.44 \mathrm{E}-05$ \\
\hline GPCR downstream signaling & EGFR & $633(633)$ & $\begin{array}{l}\text { HMDB00181; HMDB00220; HMDB00674; } \\
\text { HMDB00564; HMDB01388; HMDB00806; } \\
\text { HMDB60102; HMDB01043; HMDB00207; } \\
\text { HMDB01999; HMDB02183 }\end{array}$ & $118(152)$ & 4.78E-05 & 0.00327 \\
\hline Signal transduction & $\begin{array}{l}\text { CTNNB1; EGFR; } \\
\text { MMP9 }\end{array}$ & $2431(2432)$ & $\begin{array}{l}\text { HMDB00181; HMDB00220; HMDB00674; } \\
\text { HMDB00222; HMDB00564; HMDB01388; } \\
\text { HMDB00806; HMDB60102; HMDB01043; } \\
\text { HMDB00207; HMDB01999; HMDB02183 }\end{array}$ & $206(290)$ & 0.000224 & 0.0119 \\
\hline Signaling by GPCR & EGFR & $706(706)$ & $\begin{array}{l}\text { HMDB00181; HMDB00220; HMDB00674; } \\
\text { HMDB00564; HMDB01388; HMDB00806; } \\
\text { HMDB60102; HMDB01043; HMDB00207; } \\
\text { HMDB01999; HMDB02183 }\end{array}$ & $142(190)$ & 0.000233 & 0.0119 \\
\hline Spinal cord injury & EGFR; MMP9 & $117(117)$ & HMDB60102; HMDB01043 & $5(9)$ & 0.000646 & 0.0255 \\
\hline $\begin{array}{l}\text { GnRH signaling pathway - } \\
\text { Homo sapiens (human) }\end{array}$ & EGFR & 93 (93) & HMDB00674; HMDB60102; HMDB01043 & $6(6)$ & 0.00135 & 0.0419 \\
\hline $\begin{array}{l}\text { Relationship between } \\
\text { inflammation_COX-2 and } \\
\text { EGFR }\end{array}$ & EGFR & $25(25)$ & HMDB60102; HMDB01043 & $1(2)$ & 0.00153 & 0.0442 \\
\hline
\end{tabular}

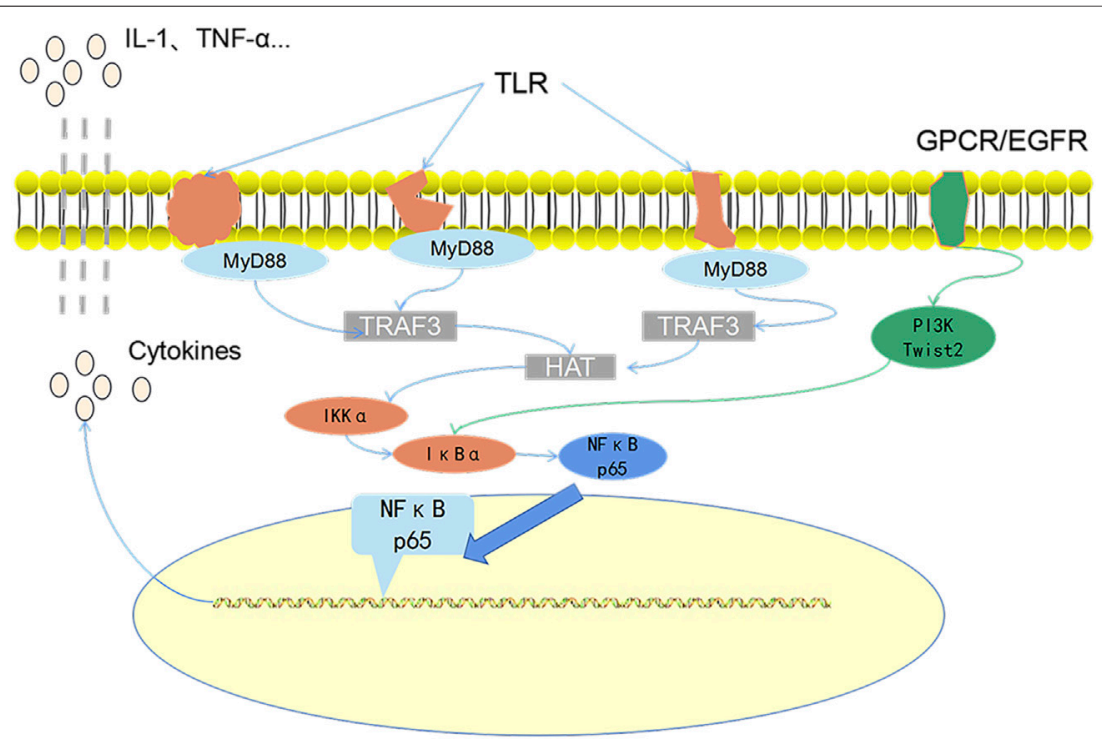

FIGURE 10 | The core role path diagram. MP is specifically recognized by toll-like receptors and then promotes the activation of the NF- $\kappa B$ pathway by promoting the expression of MyD88 protein. This is also the main path of MPP pathogenesis. Both G-protein-coupled receptors and EGF receptors that can pass the direct or indirect pathway is positively correlated with the NF-kB pathway.

acid and linoleic acid combine with lipoxygenase to promote the secretion of IL- 6 and TNF- $\alpha$ by macrophages through the production of prostaglandins and leukotrienes (Das, 2010; Poorani et al., 2016). When the inflammation invasion reaches the second stage, it can promote the conversion to macrophages from the M1 type to M2 type and promote the release of IL-4, IL-10, etc (Das, 2018). In this experiment, whether it is the level of lipid metabolism or the Th1 and Th2 type, cytokines are highly expressed in the MPP group, which reflects metabolic disorders. The abnormality of amino acid metabolism is believed to be directly related to immune regulation. By regulating the phosphorylation of MyD88, inflammation is regulated to promote the release of TNF- $\alpha$ and IL-1 $\beta$ (Gurung et al., 2017). 


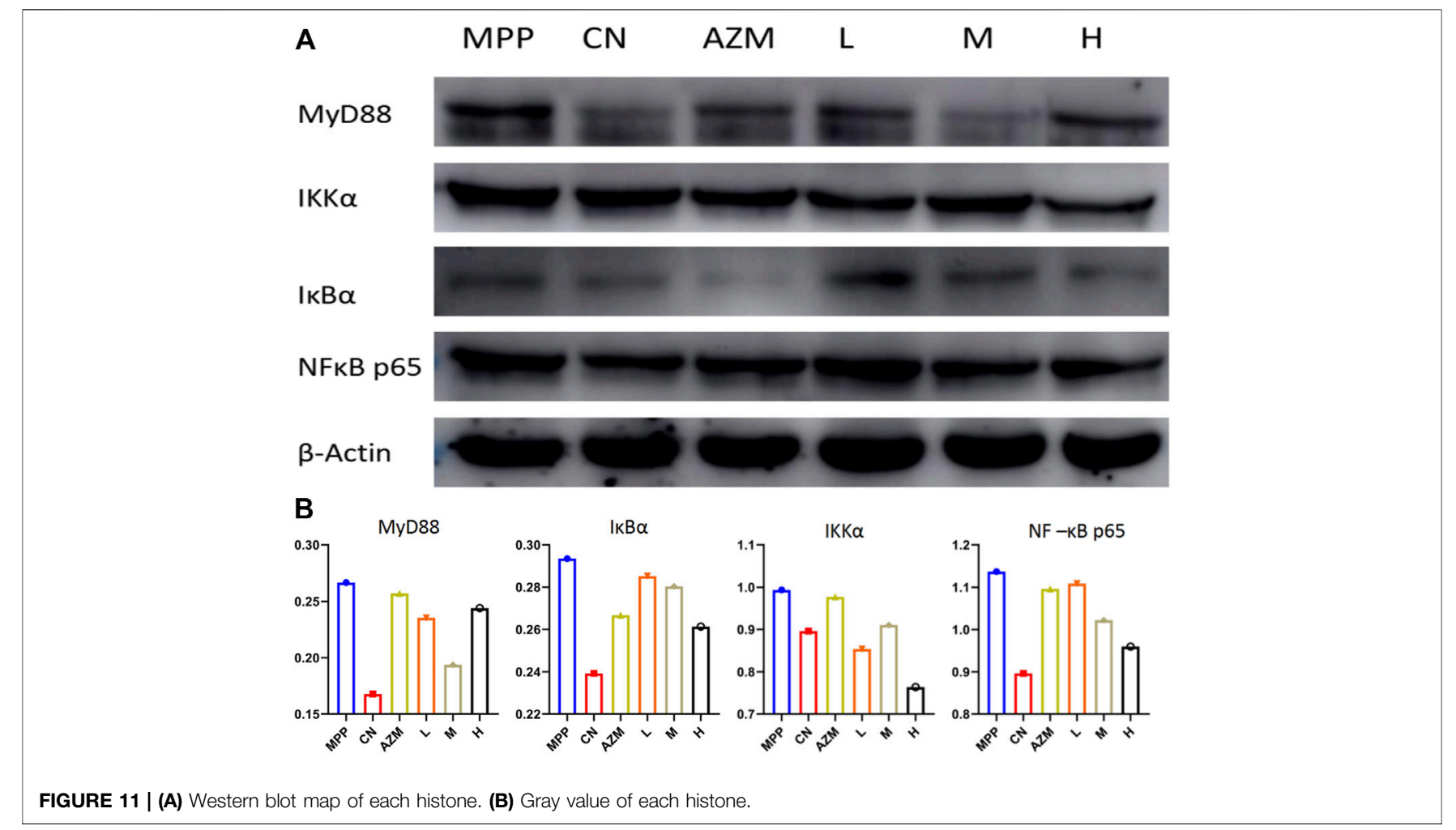

SIRT1 can inhibit SREBP1 and further downregulate pirin (PIR) and nod-like receptor protein 3 (NLRP3) inflammasomes, deacetylating FOXO3, NF- $\mathrm{BB}$, and p532 to achieve the purpose of inhibiting inflammation (Sun et al., 2009). It can promote synthesis inhibiting activity of eNOS oxidase slow oxidative stress (Zhang et al., 2020) and to protect lung tissue. MMP9 (matrix metallopeptidase 9) is a protease related to the reconstruction process of lung pathology. It interferes with the transport of eosinophils and is usually produced by a variety of airway cells, especially airway epithelial cells (Kong et al., 2014). MMP9 can be released from activated white blood cells, reduce the level of E-cadherin in lung tissue (Xie X. et al., 2020) and by intervening in the accumulation of neutrophils and eosinophils. It can promote the killing of pathogens and inhibit excessive inflammation (Lu et al., 2008; Kong et al., 2014). CTNNB1 is the gene encoding $\beta$-catenin and is a key part of the Wnt signaling pathway. It is essential for cell proliferation, differentiation, and function. It plays an important role in stem cell renewal and organ regeneration under normal physiological conditions. CTNNB1 stimulates the phosphorylation of $\beta$-catenin and the transfer inside and outside the cell and in this process stimulates $\mathrm{T}$-cell factors to maintain the stability of the immune system (Ridker and Lüscher, 2014). CTNNB1 abnormal expression is often closely related to the development of tumors, for its role in pneumonia is also thought to be immune homeostasis or not the citizenry. The epidermal growth factor receptor (EGFR) can promote the repair of respiratory epithelial cells and promote the expression of inflammatory factors (Harada et al., 2011).
EGFR proteins, while reducing mucus generated by adjusting IRFs and exogenous IFN- $\gamma$ against the invasion of pathogens, appear to strengthen the inflammatory infiltrate in the process (Kalinowski et al., 2018).

Finally, the enrichment analysis of them found out their relationship with the NF- $\kappa \mathrm{B}$ pathway and finally confirmed the relationship between them. The final protein expression verification confirmed the above conjecture. MPP triggers the activation of toll-like receptors and a series of downstream proteins and inflammatory signal factors are therefore expressed. Immune damage and pathogen damage simultaneously damage the lung tissue. QB, through the regulation of related targets after administration, ultimately affects the NF- $\kappa \mathrm{B}$ pathway, resulting in changes in downstream biomarkers.

Based on the present observations, QB can inhibit the proliferation of MP in lung tissues. It acts on SIRT1, IL-10, MMP9, CTNNB1, EGFR, and other targets through luteolin, guanosine, wogonin, isorhamnetin, and other components. Finally, by inhibiting the NF- $\mathrm{B}$ signaling pathway, it regulates the release of inflammatory factors and inhibits the excessive Th2 response, which has the effects of regulating metabolism, curing diseases, and repairing lung tissue.

\section{DATA AVAILABILITY STATEMENT}

The raw data supporting the conclusions of this article will be made available by the authors, without undue reservation. 


\section{ETHICS STATEMENT}

The animal study was reviewed and approved by the Ethics Committee of the Heilongjiang Academy of Chinese Medicine.

\section{AUTHOR CONTRIBUTIONS}

$\mathrm{ZL}$ and J-hH: Conceive ideas and complete experiments. G-dS and W-tD: Data collection and arrangement. F-jL: Animal experiment implementation. Y-nZ: Article revision. Z-wQ and Jp: Supportive work. W-mW: Design and fund experiments.

\section{REFERENCES}

Alishlash, A. S., Atkinson, T. P., Schlappi, C., Leal, S. M., Waites, K. B., and Xiao, L. (2019). Mycoplasma Pneumoniae Carriage with De Novo Macrolide-Resistance and Breakthrough Pneumonia. Pediatrics 144 (4), e20191642. doi:10.1542/ peds.2019-1642

Almagor, M., Kahane, I., and Yatziv, S. (1984). Role of Superoxide Anion in Host Cell Injury Induced by Mycoplasma Pneumoniae Infection. A Study in normal and Trisomy 21 Cells. J. Clin. Invest. 73 (3), 842-847. doi:10.1172/JCI111279

Atkinson, T. P., Balish, M. F., and Waites, K. B. (2008). Epidemiology, Clinical Manifestations, Pathogenesis and Laboratory Detection of Mycoplasma Pneumoniae Infections. FEMS Microbiol. Rev. 32 (6), 956-973. doi:10.1111/ j.1574-6976.2008.00129.x

Bajantri, B., Venkatram, S., and Diaz-Fuentes, G. (2018). Mycoplasma Pneumoniae: A Potentially Severe Infection. J. Clin. Med. Res. 10 (7), 535-544. doi:10.14740/jocmr3421w

Birt, D. F., Hendrich, S., and Wang, W. (2001). Dietary Agents in Cancer Prevention: Flavonoids and Isoflavonoids. Pharmacol. Ther. 90, 157-177. doi:10.1016/s0163-7258(01)00137-1

Blyth, C. C., and Gerber, J. S. (2018). Macrolides in Children with CommunityAcquired Pneumonia: Panacea or Placebo. J. Pediatr. Infect Dis Soc 7 (1), 71-77. doi:10.1093/jpids/pix083

Chen, J., Ullah, H., Zheng, Z., Gu, X., Su, C., Xiao, L., et al. (2020b). Soyasaponins Reduce Inflammation by Downregulating MyD88 Expression and Suppressing the Recruitments of TLR4 and MyD88 into Lipid Rafts. BMC Complement. Med. Ther. 20 (1), 167. doi:10.1186/s12906-020-2864-2

Chen, J. W., Rice, T. A., Bannock, J. M., Bielecka, A. A., Strauss, J. D., Catanzaro, J. R., et al. (2020a). Autoreactivity in Naïve Human Fetal B Cells Is Associated with Commensal Bacteria Recognition. Science 369 (6501), 320-325. doi:10.1126/science.aay9733

Chuffa, L. G., Fioruci-Fontanelli, B. A., Mendes, L. O., Ferreira Seiva, F. R., Martinez, M., Fávaro, W. J., et al. (2015). Melatonin Attenuates the TLR4Mediated Inflammatory Response Through MyD88- and TRIF-dependent Signaling Pathways in an In Vivo Model of Ovarian Cancer. BMC Cancer 15, 34. doi:10.1186/s12885-015-1032-4

Collis, M. C. (2006). Integrative Pharmacology and Drug Discovery-Iis the Tide Finally Turning. Nat. Rev. Drug Discov. 5 (5), 377-379. doi:10.1038/ $\operatorname{nrd} 2036$

Cronin, J. G., Turner, M. L., Goetze, L., Bryant, C. E., and Sheldon, I. M. (2012). Toll-like Receptor 4 and MYD88-dependent Signaling Mechanisms of the Innate Immune System Are Essential for the Response to Lipopolysaccharide by Epithelial and Stromal Cells of the Bovine Endometrium. Biol. Reprod. 86 (2), 51. doi:10.1095/biolreprod.111.092718

Das, U. N. (2018). Arachidonic Acid and Other Unsaturated Fatty Acids and Some of Their Metabolites Function as Endogenous Antimicrobial Molecules: A Review. J. Adv. Res. 11, 57-66. doi:10.1016/j.jare.2018.01.001

Das, U. N. (2010). Current and Emerging Strategies for the Treatment and Management of Systemic Lupus Erythematosus Based on Molecular Signatures of Acute and Chronic Inflammation. J. Inflamm. Res. 3, 143-170. doi:10.2147/JIR.S9425

\section{FUNDING}

This work was partially supported by the National Natural Science Foundation of China (grant numbers 81371045) and the high-level talent funding project of Hebei province (grant numbers B2019003029).

\section{ACKNOWLEDGMENTS}

Thanks to the researcher Yan-li Meng for providing the standard strain of Mycoplasma pneumoniae.

Ding, Y., Wang, Y., Li, C., Zhang, Y., Hu, S., Gao, J., et al. (2021). a-Linolenic Acid Attenuates Pseudo-allergic Reactions by Inhibiting Lyn Kinase Activity. Phytomedicine 80, 153391. doi:10.1016/j.phymed.2020.153391

Gurung, P., Fan, G., Lukens, J. R., Vogel, P., Tonks, N. K., and Kanneganti, T. D. (2017). Tyrosine Kinase SYK Licenses MyD88 Adaptor Protein to Instigate IL1a-Mediated Inflammatory Disease. Immunity 46 (4), 635-648. doi:10.1016/ j.immuni.2017.03.014

Hamilos, D. L. (2015). Drivers of Chronic Rhinosinusitis: Inflammation Versus Infection. J. Allergy Clin. Immunol. 136 (6), 1454-1459. doi:10.1016/ j.jaci.2015.10.011

Harada, C., Kawaguchi, T., Ogata-Suetsugu, S., Yamada, M., Hamada, N., Maeyama, T., et al. (2011). EGFR Tyrosine Kinase Inhibition Worsens Acute Lung Injury in Mice with Repairing Airway Epithelium. Am. J. Respir. Crit. Care Med. 183 (6), 743-751. doi:10.1164/rccm.201002-0188OC

Hendriks, J. J., Alblas, J., van der Pol, S. M., van Tol, E. A., Dijkstra, C. D., and de Vries, H. E. (2004). Flavonoids Influence Monocytic GTPase Activity and Are Protective in Experimental Allergic Encephalitis. J. Exp. Med. 200 (12) 1667-1672. doi:10.1084/jem.20040819

Hsieh, W. Y., Zhou, Q. D., York, A. G., Williams, K. J., Scumpia, P. O., Kronenberger, E. B., et al. (2020). Toll-Like Receptors Induce Signal-specific Reprogramming of the Macrophage Lipidome. Cell Metab 32 (1), 128-143.e5. doi:10.1016/j.cmet.2020.05.003

Kalinowski, A., Galen, B. T., Ueki, I. F., Sun, Y., Mulenos, A., Osafo-Addo, A., et al. (2018). Respiratory Syncytial Virus Activates Epidermal Growth Factor Receptor to Suppress Interferon Regulatory Factor 1-dependent InterferonLambda and Antiviral Defense in Airway Epithelium. Mucosal Immunol. 11 (3), 958-967. doi:10.1038/mi.2017.120

Kannan, T. R., and Baseman, J. B. (2006). ADP-ribosylating and Vacuolating Cytotoxin of Mycoplasma Pneumoniae Represents Unique Virulence Determinant Among Bacterial Pathogens. Proc. Natl. Acad. Sci. U S A. 103 (17), 6724-6729. doi:10.1073/pnas.0510644103

Kannan, T. R., Hardy, R. D., Coalson, J. J., Cavuoti, D. C., Siegel, J. D., Cagle, M., et al. (2012). Fatal Outcomes in Family Transmission of Mycoplasma Pneumoniae. Clin. Infect. Dis. 54 (2), 225-231. doi:10.1093/cid/cir769

Karimi, M. G., and Arababadi, M. K. (2014). TLR3 Plays Significant Roles Against Hepatitis B Virus. Mol. Biol. Rep. 41 (5), 3279-3286. doi:10.1007/s11033-0143190-x

Khoury, T., Sviri, S., Rmeileh, A. A., Nubani, A., Abutbul, A., Hoss, S., et al. (2016). Increased Rates of Intensive Care Unit Admission in Patients with Mycoplasma Pneumoniae: A Retrospective Study. Clin. Microbiol. Infect. 22 (8), 711-714. doi:10.1016/j.cmi.2016.05.028

Koh, Y. Y., Park, Y., Lee, H. J., and Kim, C. K. (2001). Levels of Interleukin-2, Interferon-Gamma, and Interleukin-4 in Bronchoalveolar Lavage Fluid from Patients with Mycoplasma Pneumonia: Implication of Tendency Toward Increased Immunoglobulin E Production. Pediatrics 107 (3), E39. doi:10.1542/peds.107.3.e39

Kong, M. Y., Clancy, J. P., Peng, N., Li, Y., Szul, T. J., Xu, X., et al. (2014). Pulmonary Matrix Metalloproteinase- 9 Activity in Mechanically Ventilated Children with Respiratory Syncytial Virus. Eur. Respir. J. 43 (4), 1086-1096. doi:10.1183/09031936.00105613

Ku, Y. S., Ng, M. S., Cheng, S. S., Wing-Yi, L. A., Lo, A. W., Xiao, Z., et al. (2020). Understanding the Composition, Biosynthesis, Accumulation and Transport of 
Flavonoids in Crops for the Promotion of Crops as Healthy Sources of Flavonoids for Human Consumption. Nutrients 12 (6), 1717. doi:10.3390/ nu12061717

Kumar, S. (2018). Mycoplasma Pneumoniae: A Significant but Underrated Pathogen in Paediatric Community-Acquired Lower Respiratory Tract Infections. Indian J. Med. Res. 147 (1), 23-31. doi:10.4103/ijmr.IJMR_1582_16

Lehman, H. L., Kidacki, M., and Stairs, D. B. (2020). Twist2 Is NFkB-Responsive when P120-Catenin Is Inactivated and EGFR Is Overexpressed in Esophageal Keratinocytes. Sci. Rep. 10 (1), 18829. doi:10.1038/s41598-020-75866-0

Li, H., Lou, R., Xu, X., Xu, C., Yu, Y., Xu, Y., et al. (2021). The Variations in Human Orphan G Protein-Coupled Receptor QRFPR Affect PI3K-AKT-mTOR Signaling. J. Clin. Lab. Anal. 35 (7), e23822. doi:10.1002/jcla.23822

Li, J. (2020). Introduction to Traditional Chinese Medicine[Compilation and Dissemination of ]. Zhonghua Yi Shi Za Zhi 50 (1), 21-27. doi:10.3760/ cma.j.issn.0255-7053.2020.01.004

Lin, J. J., Lin, K. L., Chiu, C. H., Hsia, S. H., Wang, H. S., Chou, I. J., et al. (2014). Antineuronal Antibodies and Infectious Pathogens in Severe Acute Pediatric Encephalitis. J. Child. Neurol. 29 (1), 11-16. doi:10.1177/0883073812461944

Liu, J., Wang, R., and Fang, M. (2020). Clinical and Drug Resistance Characteristics of Providencia Stuartii Infections in 76 Patients. J. Int. Med. Res. 48 (10), 300060520962296. doi:10.1177/0300060520962296

Liu, Y., Ye, X., Zhang, H., Xu, X., Li, W., Zhu, D., et al. (2009). Antimicrobial Susceptibility of Mycoplasma Pneumoniae Isolates and Molecular Analysis of Macrolide-Resistant Strains from Shanghai, China. Antimicrob. Agents Chemother. 53 (5), 2160-2162. doi:10.1128/AAC.01684-08

Lowry, J. R., Marshall, N., Wenzel, T. J., Murray, T. E., and Klegeris, A. (2020). The Dietary Fatty Acids $a$-linolenic Acid (ALA) and Linoleic Acid (LA) Selectively Inhibit Microglial Nitric Oxide Production. Mol. Cell Neurosci 109, 103569. doi:10.1016/j.mcn.2020.103569

Lu, J., Marnell, L. L., Marjon, K. D., Mold, C., Du Clos, T. W., and Sun, P. D. (2008). Structural Recognition and Functional Activation of $\mathrm{F} c \gamma \mathrm{R}$ by Innate pentraxinsStructural Recognition and Functional Activation of FcgammaR by Innate Pentraxins. Nature 456 (7224), 989-992. doi:10.1038/nature07468

Lye, E., Mirtsos, C., Suzuki, N., Suzuki, S., and Yeh, W. C. (2004). The Role of Interleukin 1 Receptor-Associated Kinase-4 (IRAK-4) Kinase Activity in IRAK4-Mediated Signaling. J. Biol. Chem. 279 (39), 40653-40658. doi:10.1074/ jbc.M402666200

Meng, Y., Huo, J., Lu, W., Wang, X., Zhang, J., and Wang, W. (2012). Modulation of P1 and EGF Expression by Baicalin. Int. J. Mol. Sci. 14 (1), 146-157. doi:10.3390/ijms 14010146

Meng, Y., Yang, Y., Lu, W., Wang, Y., Qian, F., Wang, X., et al. (2014). The Inhibition of Platycodin D on Mycoplasma Pneumoniae Proliferation and its Effect on Promoting Cell Growth After Anti-mycoplasma Pneumoniae Treatment. Front Cell Infect Microbiol 4, 192. doi:10.3389/fcimb.2014.00192

Meng, Y. L., Wang, W. M., Lv, D. D., An, Q. X., Lu, W. H., Wang, X., et al. (2017). The Effect of Platycodin D on the Expression of Cytoadherence Proteins P1 and P30 in Mycoplasma Pneumoniae Models. Environ. Toxicol. Pharmacol. 49, 188-193. doi:10.1016/j.etap.2017.01.001

Merrell, D. S., and Falkow, S. (2004). Frontal and Stealth Attack Strategies in Microbial Pathogenesis. Nature 430 (6996), 250-256. doi:10.1038/ nature 02760

Naghib, M., Hatam-Jahromi, M., Niktab, M., Ahmadi, R., and Kariminik, A. (2018). Mycoplasma Pneumoniae and Toll-like Receptors: A Mutual Avenue. Allergol. Immunopathol (Madr) 46 (5), 508-513. doi:10.1016/j.aller.2017.09.021

Narita, M. (2009). Pathogenesis of Neurologic Manifestations of Mycoplasma Pneumoniae Infection. Pediatr. Neurol. 41 (3), 159-166. doi:10.1016/ j.pediatrneurol.2009.04.012

Onozuka, D., Hashizume, M., and Hagihara, A. (2009). Impact of Weather Factors on Mycoplasma Pneumoniae Pneumonia. Thorax 64 (6), 507-511. doi:10.1136/ thx.2008.111237

Parnell, G. P., McLean, A. S., Booth, D. R., Armstrong, N. J., Nalos, M., Huang, S. J., et al. (2012). A Distinct Influenza Infection Signature in the Blood Transcriptome of Patients with Severe Community-Acquired Pneumonia. Crit. Care 16 (4), R157. doi:10.1186/cc11477

Poorani, R., Bhatt, A. N., Dwarakanath, B. S., and Das, U. N. (2016). COX-2, Aspirin and Metabolism of Arachidonic, Eicosapentaenoic and Docosahexaenoic Acids and Their Physiological and Clinical Significance. Eur. J. Pharmacol. 785, 116-132. doi:10.1016/j.ejphar.2015.08.049
Porras, G., Chassagne, F., Lyles, J. T., Marquez, L., Dettweiler, M., Salam, A. M., et al. (2021). Ethnobotany and the Role of Plant Natural Products in Antibiotic Drug Discovery. Chem. Rev. 121 (6), 3495-3560. doi:10.1021/ acs.chemrev.0c00922

Purba, A. K., Ascobat, P., Muchtar, A., Wulandari, L., Rosyid, A. N., Purwono, P. B., et al. (2019). Multidrug-Resistant Infections Among Hospitalized Adults with Community-Acquired Pneumonia in an Indonesian Tertiary Referral Hospital. Infect. Drug Resist. 12, 3663-3675. doi:10.2147/IDR.S217842

Qian, W., Kang, A., Peng, L., Xie, T., Ji, J., Zhou, W., et al. (2018). Gas Chromatography-Mass Spectrometry Based Plasma Metabolomics of H1N1Induced Inflammation in Mice and Intervention with Flos Lonicerae JaponicaFructus Forsythiae Herb Pair. J. Chromatogr. B Analyt Technol. Biomed. Life Sci. 1092, 122-130. doi:10.1016/j.jchromb.2018.05.047

Ridker, P. M., and Lüscher, T. F. (2014). Anti-inflammatory Therapies for Cardiovascular Disease. Eur. Heart J. 35 (27), 1782-1791. doi:10.1093/ eurheartj/ehu203

Rui, Z., Chang-Pei, X., Jing-Jing, Z., and Hong-Jun, Y. (2020). Research Progress on Chemical Compositions of Coptidis Rhizoma and Pharmacological Effects of Berberine. Zhongguo Zhong Yao Za Zhi 45 (19), 4561-4573. doi:10.19540/ j.cnki.cjcmm.20200527.202

Saikh, K. U. (2021). MyD88 and beyond: A Perspective on MyD88-Targeted Therapeutic Approach for Modulation of Host Immunity. Immunol. Res. 69 (2), 117-128. doi:10.1007/s12026-021-09188-2

Saraya, T. (2017). Mycoplasma Pneumoniae Infection: Basics. J. Gen. Fam. Med. 18 (3), 118-125. doi:10.1002/jgf2.15

Shimizu, T. (2016). Inflammation-inducing Factors of Mycoplasma Pneumoniae. Front. Microbiol. 7, 414. doi:10.3389/fmicb.2016.00414

Singh, D. K., Dwivedi, V. P., SinghPrakash., S. P., Kumari, A., Sharma, S. K., Ranganathan, A., et al. (2020). Luteolin-mediated Kv1.3 K+ Channel Inhibition Augments BCG Vaccine Efficacy Against Tuberculosis by Promoting Central Memory T Cell Responses in Mice. Plos Pathog. 16 (9), e1008887. doi:10.1371/ journal.ppat.1008887

Sun, J., Madan, R., Karp, C. L., and Braciale, T. J. (2009). Effector T Cells Control Lung Inflammation during Acute Influenza Virus Infection by Producing IL10. Nat. Med. 15 (3), 277-284. doi:10.1038/nm.1929

Takeuchi, O., and Akira, S. (2010). Pattern Recognition Receptors and Inflammation. Cell 140 (6), 805-820. doi:10.1016/j.cell.2010.01.022

Tang, M., Xie, X., Yi, P., Kang, J., Liao, J., Li, W., et al. (2020). Integrating Network Pharmacology with Molecular Docking to Unravel the Active Compounds and Potential Mechanism of Simiao Pill Treating Rheumatoid Arthritis. Evid. Based Complement. Alternat Med. 2020, 5786053. doi:10.1155/2020/5786053

Tibbitt, C. A., Stark, J. M. Mario., Martens, L., Ma, J., Mold, J. E., Deswarte, K., et al. (2019). Single-Cell RNA Sequencing of the T Helper Cell Response to House Dust Mites Defines a Distinct Gene Expression Signature in Airway Th2 Cells. Immunity 51 (1), 169-184.e5. doi:10.1016/j.immuni.2019.05.014

Waites, K. B., Balish, M. F., and Atkinson, T. P. (2008). New Insights into the Pathogenesis and Detection of Mycoplasma Pneumoniae Infections. Future Microbiol. 3 (6), 635-648. doi:10.2217/17460913.3.6.635

Waites, K. B., Xiao, L., Liu, Y., Balish, M. F., and Atkinson, T. P. (2017). Mycoplasma Pneumoniae from the Respiratory Tract and beyond. Clin. Microbiol. Rev. 30 (3), 747-809. doi:10.1128/CMR.00114-16

Wang, Y., Li, H., Shi, Y., Wang, S., Xu, Y., Li, H., et al. (2020). miR-143-3p Impacts on Pulmonary Inflammatory Factors and Cell Apoptosis in Mice with Mycoplasmal Pneumonia by Regulating TLR4/MyD88/NF-Kb Pathway. Biosci. Rep. 40 (7), BSR20193419. doi:10.1042/BSR20193419

Wu, H., Ding, X., Zhao, D., Liang, Y., and Ji, W. (2019). Effect of Montelukast Combined with Methylprednisolone for the Treatment of Mycoplasma Pneumonia. J. Int. Med. Res. 47 (6), 2555-2561. doi:10.1177/0300060518820412

Wynn, T. A. (2015). Type 2 Cytokines: Mechanisms and Therapeutic Strategies. Nat. Rev. Immunol. 15 (5), 271-282. doi:10.1038/nri3831

Xie, F., Zhang, L., Yao, Q., Shan, L., Liu, J., Dong, N., et al. (2020a). TUG1 Promoted Tumor Progression by Sponging miR-335-5p and Regulating CXCR4-Mediated Infiltration of Pro-tumor Immunocytes in CTNNB1Mutated Hepatoblastoma. Onco Targets Ther. 13, 3105-3115. doi:10.2147/ OTT.S234819

Xie, X., Shi, Q., Wu, P., Zhang, X., Kambara, H., Su, J., et al. (2020b). Single-cell Transcriptome Profiling Reveals Neutrophil Heterogeneity in Homeostasis and Infection. Nat. Immunol. 21 (9), 1119-1133. doi:10.1038/s41590-020-0736-Z 
Xing, Y., Wang, D., Sheng, K., Xiao, X., Wei, H., Liu, L., et al. (2020). Dynamic Change of Mycoplasma Pneumoniae Pneumonia in Hospitalized Children in a General Hospital: A 3-year Retrospective Analysis. Transl Pediatr. 9 (4), 522-531. doi:10.21037/tp-20-149

Yamazaki, T., and Kenri, T. (2016). Epidemiology of Mycoplasma Pneumoniae Infections in Japan and Therapeutic Strategies for Macrolide-Resistant M. Pneumoniae. Front. Microbiol. 7, 693. doi:10.3389/fmicb.2016.00693

Yang, H.-J., Song, D. J., and Shim, J. Y. (2017). Mechanism of Resistance Acquisition and Treatment of Macrolide-Resistant Mycoplasma Pneumoniae Pneumonia in childrenMycoplasma pneumoniaeMechanism of Resistance Acquisition and Treatment of Macrolide-Resistant Pneumonia in Children. Korean J. Pediatr. 60 (6), 167-174. doi:10.3345/kjp.2017.60.6.167

Yang, M., Meng, F., Gao, M., Cheng, G., and Wang, X. (2019). Cytokine Signatures Associate with Disease Severity in Children with Mycoplasma Pneumoniae Pneumonia. Sci. Rep. 9 (1), 17853. doi:10.1038/s41598-019-54313-9

Zhang, S., Weinberg, S., DeBerge, M., Gainullina, A., Schipma, M., Kinchen, J. M., et al. (2019). Efferocytosis Fuels Requirements of Fatty Acid Oxidation and the Electron Transport Chain to Polarize Macrophages for Tissue Repair. Cell Metab 29 (2), 443-456.e5. doi:10.1016/j.cmet.2018.12.004

Zhang, X., Zhang, Y., Meng, Q., Sun, H., Wu, S., Xu, J., et al. (2020). MicroRNA-382-5p Is Involved in Pulmonary Inflammation Induced by Fine Particulate Matter Exposure. Environ. Pollut. 262, 114278. doi:10.1016/j.envpol.2020.114278
Zhou, Y., Zhang, Y., Sheng, Y., Zhang, L., Shen, Z., and Chen, Z. (2014). More Complications Occur in Macrolide-Resistant Than in Macrolide-Sensitive Mycoplasma Pneumoniae Pneumonia. Antimicrob. Agents Chemother. 58 (2), 1034-1038. doi:10.1128/AAC.01806-13

Conflict of Interest: The authors declare that the research study was conducted in the absence of any commercial or financial relationships that could be construed as a potential conflict of interest.

Publisher's Note: All claims expressed in this article are solely those of the authors and do not necessarily represent those of their affiliated organizations or those of the publisher, the editors, and the reviewers. Any product that may be evaluated in this article or claim that may be made by its manufacturer is not guaranteed or endorsed by the publisher.

Copyright (c) 2021 Liu, Huo, Dong, Sun, Li, Zhang, Qin, pengna and Wang. This is an open-access article distributed under the terms of the Creative Commons Attribution License (CC BY). The use, distribution or reproduction in other forums is permitted, provided the original author(s) and the copyright owner(s) are credited and that the original publication in this journal is cited, in accordance with accepted academic practice. No use, distribution or reproduction is permitted which does not comply with these terms. 